\title{
RADIOMETRIC AGES AND OTHER ISOTOPIC DATA BEARING ON THE EVOLUTION OF ARCHAEAN CRUST AND ORES IN THE KUHMO- SUOMUSSALMI AREA, EASTERN FINLAND
}

\author{
MATTI VAASJOKI, KALLE TAIPALE and ILKKA TUOKKO
}

VAASJOKI, MATTI, TAIPALE, KALLE and TUOKKO, ILKKA 1999. Radiometric ages and other isotopic data bearing on the evolution of Archaean crust and ores in the Kuhmo-Suomussalmi area, eastern Finland. Bulletin of the Geological Society of Finland 71, Part 1, 155-176.

The Archaean greenstone-gneiss terrain in the Kuhmo-Suomussalmi district in eastern Finland has been isotopically studied in connection with regional bedrock mapping and local mineral exploration projects. The studies have aimed at testing correlations of lithologic units in partly poorly exposed areas, determining times of ore formation and obtaining ore genetic information in order to better understand the general evolution of the Archaean formations within the Fennoscandian Shield.

Isotopic results on 63 zircon and titanite fractions from 13 samples, common lead analyses of 14 sulphide separates from two mineral prospects and 33 whole rock $\mathrm{Pb}-\mathrm{Pb}$ analyses warrant the following conclusions:

1) Although some dates in excess of $3 \mathrm{Ga}$ have been determined from the Finnish Archaean, most of the granite gneiss terrain was formed between 2.85 and $2.65 \mathrm{Ga}$ with a major period of rock formation from about 2.75 to $2.69 \mathrm{Ga}$.

2) The majority of the metavolcanic rocks within the Kuhmo-Suomussalmi greenstone belt are $2.79 \mathrm{Ga}$ old, but the meta-andesites of the Luoma Group are distinctly older at $2.97 \mathrm{Ga}$.

3) The Taivaljärvi Ag- $\mathrm{Zn}-\mathrm{Pb}$ deposit appears to be syngenetic with the local metavolcanic rocks and is thus $2.79 \mathrm{Ga}$ old. Its lead probably represents the initial lead of both mafic and felsic metavolcanic rocks in the area.

4) When compared to the Abitibi region in Canada, the available $\mathrm{Pb}-\mathrm{Pb}$ data may suggest a heterogeneous Archaean mantle, but as even this study shows, common lead data is inconclusive evidence, as it may be easily influenced by later hydrothermal processes.

Key words: Archean, absolute age, $\mathrm{U} / \mathrm{Pb}, \mathrm{Pb} / \mathrm{Pb}$, zircon, titanite, sulfides, whole rock, tonalite, granites, gneisses, metavolcanic rocks, greenstone belts, Kuhmo, Suomussalmi, Finland

Matti Vaasjoki and Kalle Taipale: Geological Survey, P.O. Box 96, FIN-02151 Espoo, Finland

E-mail: matti.vaasjoki@gsf.fi

Ilkka Tuokko: Finnminerals OY, A603, FIN-88999, Kajaani, Finland 


\section{INTRODUCTION}

The isotope study of the Finnish Archaean has been long and varied. After initial U-Pb work on zircons established the ancient nature of the granitoid rocks (Wetherill et al. 1962, Kouvo \& Tilton 1966), the Kuhmo-Suomussalmi belt (Fig. 1) in Finland was one of the first greenstone belts to receive district-wide isotopic attention (Vidal et al. 1980), and it was shown that lead isotopic data from various rock types ranging from komatiitic lavas to surrounding granitoids plotted on a linear trend yielding an age estimate of $2660 \pm 80 \mathrm{Ma}$. Subsequently, both the surrounding granitoids and the greenstone belt rocks themselves were studied by the $\mathrm{Rb}$-Sr and $\mathrm{Sm}-\mathrm{Nd}$ methods from whole rock samples (Martin \& Quérré 1984, Martin et al. 1983) as well as by the U-Pb method from zir- cons and titanites (Hyppönen 1983, Luukkonen 1985, 1988). Many grey gneisses appear to be derived from mantle material, but other gneisses have elevated initial Sr-ratios and exhibit negative $\varepsilon_{\mathrm{Nd}}$ values (Jahn et al. 1984), and thus seem to be rejuvenated continental crust. A similar conclusion was also derived from galena occurrences of the Archaean domain (Vaasjoki 1989).

The interpretation of these results led to some controversy on the age of the greenstone emplacement (Barbey \& Martin 1987, Vaasjoki 1988, Martin \& Barbey 1988). In short, one school favours an emplacement at 2700-2800 Ma because zircons and titanites in the area register ages of that order. The other line of thought discounts the $\mathrm{U}-\mathrm{Pb}$ evidence as arising from inherited phases and considers that the $\mathrm{Rb}-\mathrm{Sr}$ whole rock data at $2500 \pm 100 \mathrm{Ma}$ represent the emplacement age. A

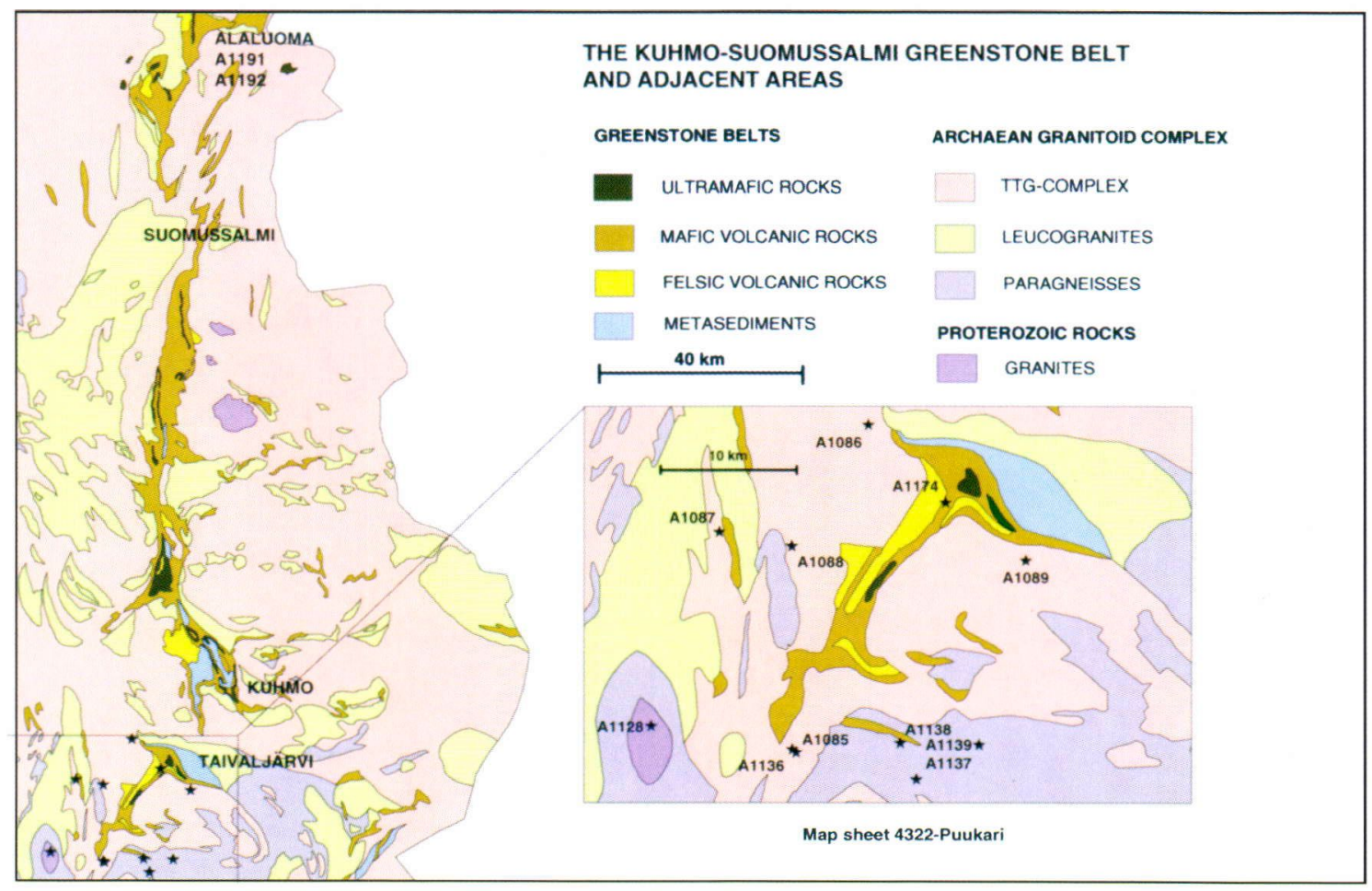

Fig. 1. Location of the study areas and the sampling sites within the Kuhmo-Suomussalmi greenstone belt in eastern Finland. 
way out of this dilemma was suggested by Halliday et al. (1988), who considered that the $\mathrm{Rb}-\mathrm{Sr}$ properties of the granitoids could be accounted for by a continuous isotopic homogenization prior to uplift. They qualified their view, however, by stating that the mechanism for such large-scale fluid transfer is not yet well understood. This idea has been developed further by Gruau et al. (1992), who suggested that resetting of the whole rock and mineral $\mathrm{Rb}-\mathrm{Sr}$ and $\mathrm{Sm}-\mathrm{Nd}$ systems may have been caused by $\mathrm{CO}_{2}$-rich fluids circulated in the rocks during a Proterozoic tectonic event.

\section{GEOLOGICAL BACKGROUND}

\section{Lithology and structural geology}

The Archaean granitoid rocks in the central Fennoscandian (Baltic) Shield are commonly divided into three groups: 1) grey gneisses, 2) tonalites and granodiorites intruding the greenstone belts, and 3) potassium-rich granites (Gaál et al. 1978, Hyppönen 1983, Luukkonen 1985, Martin et al. 1983, Horneman et al. 1988). The first two groups consist mainly of TTG-type granitoids (Martin 1987), whereas the third is highly siliceous and potassic and exhibits REE patterns with distinct negative Eu-anomalies (Horneman et al. 1988).

Towards the greenstone belt, the gneiss complex grades into a cataclastic, leucocratic tonalite, which forms the most abundant rock type in contact with the supracrustal rocks. The contacts of the tonalite towards the greenstone belt are tectonic and sharp. Banded amphibolite occurs both in the greenstone belt and in the gneisses as narrow, deformed lenses.

Layered mafic-ultramafic sills (and, in places, lavas) form the predominant rock unit in the lower part of the greenstone complex. Some of the sills are $10 \mathrm{~km}$ long and $800 \mathrm{~m}$ wide and intrude the tholeiitic banded amphibolite. The ultramafic portion of the sill consists of peridotitic komatiites and serpentinites boudinaged during the almost isoclinal $\mathrm{F}_{3}$ folding. Mafic rocks occur as concordant, foliated dykes with the ultramafic sills and sometimes form gabbro bodies. A pegmatoid portion from such a metagabbro has been dated by $\mathrm{U}-\mathrm{Pb}$ from zircons at $2790 \pm 18 \mathrm{Ma}$ (Luukkonen 1988).

The most abundant rocks in the middle succession of the greenstone belt are deformed ( \pm peridotitic)-pyroxenitic-basaltic komatiites. Although these units appear to be several hundred metres thick, they are, at least at Moisionvaara, a repetition of layers only a few tens of metres thick, folded isoclinally during the $\mathrm{F}_{3}$ phase. Intensely folded black schists, phyllites and banded iron formations are associated with these mafic-ultramafic rocks.

Deformed, polymictic conglomerates and sericite quartzites occur in places. The formation was originally a few tens of metres thick, but because of regional folding and faulting $\left(D_{3}\right)$ it is repeated and may be up to $200 \mathrm{~m}$ thick. Vein quartz clasts appear to have been predominantly subspherical while mafic pebbles from the lower part of the succession are frequently elongated and mylonitized. Heterogeneous detrital zircon from this rock is $2800-3000$ Ma old (Olavi Kouvo, personal communication 1993). Thus both the greenstone belt itself and the grey gneisses appear to be the principal sources for this metasedimentary unit.

The composition of felsic metavolcanics within the Kuhmo-Suomussalmi belt ranges from dacites to rhyolites. Meta-andesites occur only in the presumed lowermost parts, and form the Luoma Group in the northern end of the belt. In contrast to the mafic-ultramafic rocks, which are of regional extent, the felsic metavolcanics of the greenstone belt seem to occur more locally. Most likely, they formed five or six separate volcanic centres along the belt. Thus the use of felsic metavolcanic rocks as stratigraphic marker horizons is questionable.

Pyroclastic rocks are common in all felsic volcanic centres. They range from breccias and tuffs to a variety of epiclastic felsic volcanics. It is difficult to distinguish felsic lavas from other quartzfeldspathic rocks in the belt, but the well-preserved quartz-feldspar porphyries in the Taivaljärvi and Juurikkaniemi areas are probably of a 
primary igneous origin. They are fine-grained quartz-feldspar-mica rocks with idiomorphic feldspar and quartz phenocrysts.

Occasionally, at the margin of the greenstone belt between the banded amphibolite and the leucocratic tonalite, porphyritic quartz diorites and biotite tonalites cut the greenstones as dykes conformable with the $\mathrm{S}_{3}$ foliation. The U-Pb data for zircons and titanites from these rocks range from 2740 to $2690 \mathrm{Ma}$, indicating that no high temperature event has affected these rocks since Archaean times.

Almost undeformed granite porphyry dykes cut the cataclastic leucotonalites. The rock is unfoliated and fine-grained close to the contacts. Sometimes weak lamination interpreted as a primary flow structure is visible. The dykes are widely distributed east of the greenstones and are considered apophyses formed during an extensive post-orogenic magmatic event. A zircon age of $2435 \pm 12$ Ma (Luukkonen 1988) has been obtained from one of these dykes.

The youngest rocks in the area are metadiabase dykes transgressing the greenstones and the surrounding granitoids. They are considered to be products of several Palaeoproterozoic rifting periods.

\section{Stratigraphy}

According to the stratigraphic map of Middle Finland (Luukkonen \& Lukkarinen 1986), the Kuhmo-Suomussalmi belt forms the Kianta Supergroup which is further divided into the upper and lower Kuhmoan Groups. During their research in the intensely deformed greenstones various workers have recognized several volcano-sedimentary successions in different subareas, of which the Luoma Group is considered to be lowest in stratigraphy, while the Ontojärvi Group forms the highest part of the Kuhmoan series.

Several problems have been encountered in the unravelling of the stratigraphy within the KuhmoSuomussalmi greenstone belt. One is the position of the leucotonalites, which Luukkonen and Lukkarinen (1986) tentatively equated with the Luoma metavolcanics. However, Luukkonen
(1988) considers that in the Moisionvaara area the gneisses grade into leucotonalite, which is separated from the greenstone belt by a tectonic contact. Thus the greenstone belt would start in this area with mafic metavolcanic rocks belonging to the lower Kuhmoan series.

A more fundamental dispute has arisen from the findings of the Oulu group, whose case is best summarized by Taipale (1988). According to him, the felsic metavolcanics always underlie associated mafic rocks, which deviates from the traditional Barberton model (Anhaeusser 1971) generally accepted for greenstone belts. This discrepancy with accepted theory has led to some doubt as to the stratigraphic correlations within the Finnish greenstone belts (e.g. Barbey \& Martin 1987). Moreover, Engel and Dietz (1989) have argued that in the Saarikylä area, in the northern tip of the greenstone belt, mafic metavolcanics form the oldest extrusive phase of the Luoma Group that otherwise consists of andesitic rocks. Thus these mafic rocks could be the oldest metavolcanics in the Kuhmo-Suomussalmi greenstone belt.

\section{THE BASEMENT GNEISS COMPLEX: AN EXAMPLE FROM THE PUUKARI MAP SHEET AREA}

\section{Purpose of the study and sample material}

One problem in the Finnish Archaean areas is the variation in the quality of outcrop. Several square kilometres of well exposed rocks may be surrounded by boggy areas with negligible outcrop. As a rule, contacts between different granitoid intrusions cannot be observed. Large scale migmatization also confuses the picture and it has been shown that at least in one case there is a $150 \mathrm{Ma}$ age difference between the migmatitic palaeosome and the granitic neosome of a complex migmatite (Luukkonen 1985). Polyphase deformation is often a useful local tool, but there is no certainty about the continuity and orientation of structures across possible block boundaries, and establishing block boundaries in poorly outcropping granitoid areas, for example on the basis of geophysics, is a problem in itself. 
The purpose of this study was to analyse a number of granitoids from a restricted area concomitant with ongoing regional mapping in order to test the feasibility of recognizing different age groups of Archaean granitoid rocks in the field. Apart of this practical goal, it was also hoped that the evolution of the Fennoscandian Archaean bedrock particularly in the vicinity of the KuhmoSuomussalmi greenstone belt could be better understood.

The study area (Fig. 1) was map sheet 4322Puukari (Taipale et al. 1993) investigated during the regional 1:100 000 mapping programme of the Geological Survey of Finland. The abundantly occurring migmatitic granitoids are divided into two areas by the mainly NE-SW striking Tipasjärvi greenstones, which form the southern end of the over $200 \mathrm{~km}$ long Kuhmo-Suomussalmi greenstone belt. The Taivaljärvi $\mathrm{Ag}-\mathrm{Zn}-\mathrm{Pb}$ mineralisation, hosted by felsic metavolcanic rocks of the belt, occurs in the map area.

Northwest of the greenstones, the migmatites are mainly medium-grained tonalites containing light-coloured leucosome as bands conformable to the orientation of the rock. They often contain banded amphibolites as folded and boudinaged lenses. Local granitization is a typical feature. The granitic material penetrates the tonalite as conformable veins, and the rocks have been folded to form phlebitic-nebulitic migmatites. Occasionally, tonalite grades into migmatitic granite as the proportion of the leucosome increases. These rocks are represented by A1088-Vetelänvaara (Outcrop no. 34/ATH/86, Finnish basic map grid Northing 7090.28, Easting 4441.48). This tonalite has retained its poorly stromatic, magmatic features. The rock is grey, medium-grained and consists mainly of oligoclase, quartz and biotite with minor microcline, hornblende and epidote. Accessory minerals include allanite, titanite, apatite, chlorite and zircon.

In the northeastern part of the map sheet, close to the contact of the Tipasjärvi greenstones there occur slightly orientated medium-grained tonalites. On the weathering surface the rock is yellowish red, but fresh surfaces are grey. The tonalites contain epidote veins and numerous inclusions, of which dark grey, fine-grained tonalite fragments are most abundant. They usually occur as clusters of irregular fragments with diffuse margins to the host rock. Occasionally light-coloured schistose intercalations resembling felsic metavolcanic rocks are met with. However, as the contact to the greenstone belt is covered by overburden, the relationship of these intercalations to the greenstone belt metavolcanics is uncertain. This tonalite group is represented by two samples. A1086-Haasiavaara (33/RSH/86, 7099.14, 4447.54) is intensely foliated and homogeneous in appearance, but contains numerous small mafic and felsic enclaves. The tonalite consists mainly of oligoclase, quartz and biotite. Accessory minerals are epidote, allanite, titanite, zircon, microcline and chlorite. Sample material was collected on two occasions as, because of the interpretation of field data, a sample mix-up in laboratory handling was suspected. The second sample verified the original results. A1089Huuskonvaara (409/ATH/87, 7088.40, 4458.72) is weakly stromatic, medium-grained and consists of plagioclase, quartz, biotite and minor epidote. Accessory minerals are titanite, microcline, chlorite, apatite, carbonate and allanite.

In the southern part of the map sheet, between the greenstone belt and the mica gneiss area, the banded grey tonalites grade into light-coloured schollen-nebulitic rocks. A typical representative is found at A1085-Halmejärvi (399/RSH/87, 7074.60, 4441.06) where a nebulitic tonalite sometimes invades the mica gneisses, while elsewhere the mica gneisses occur as a mesosome in stromatic migmatites. The tonalite is a pale grey to pinkish, medium-grained rock. Antiperthitic oligoclase, quartz and biotite are the main rock-forming minerals with variable amounts of poikilitic hornblende. Accessory minerals include epidote, titanite and zircon. A1136-Halmejärvi (153/ATH/ $86,7074.83,4440.79$ ) is a mica gneiss inclusion in a nebulitic tonalite. The mica gneiss is grey, medium-grained and well foliated. It consists of oligoclase, quartz, biotite and minor titanite. Microcline, apatite, epidote, allanite and zircon occur as accessory minerals.

In the southern part of the map area light-grey, foliated tonalites and granodiorites invade the 
mica gneisses and contain mica gneiss fragments. At A1138-Mustalaissuo (165/RSH/86, 7074.96, $4448.78)$ the foliated granodiorite is homogeneous and consists mainly of plagioclase, quartz, muscovite and red-brown biotite with minor amounts of microcline, apatite, zircon, chlorite, epidote and opaque minerals. A1137-Riihikangas (170/ATH/86, 7072.16, 4449.84) is a gneissose granite dyke cross-cutting the mica gneisses. The granite dykes are massive, pale grey to pinkish and well foliated. Major minerals are microcline, quartz, plagioclase and minor muscovite, biotite and chlorite. Accessory minerals include opaque minerals, apatite, zircon and epidote. A1139-Tornikangas $(185 / \mathrm{RSH} / 86,7074.56,4454.62)$ represents the mica gneisses. The rock is massive, dark grey, well foliated and medium-grained. The major minerals are oligoclase, quartz and biotite. Accessory minerals include zircon, apatite, chlorite and opaque minerals.

In the western part of the map sheet there occurs a variety of granitic rocks. They are mainly tonalites migmatized by granitic material and granite veins cutting these. The latter seem to be emplaced in fracture zones, are sometimes up to $10 \mathrm{~m}$ thick and are represented by A1087-Aittolanaho (105/ATH/86, 7091.58, 4441.48). This pink granite is medium-grained and poorly foliated. It contains plagioclase, quartz, microcline and biotite together with minor amounts of magnetite, apatite, titanite, epidote and zircon.

A1128-Rasimäki (134/RSH/86, 7077.12, 4430.44) is from an intrusion of pink granite with a surface area of about $24 \mathrm{~km}^{2}$ emplaced in the southwestern part of the map area. The granite is homogeneous, undeformed and coarse-grained and clearly cross-cuts all other rocks in the area. The rock-forming minerals are quartz, microcline, oligoclase and biotite together with minor amounts of magnetite, muscovite, zircon, epidote and fluorite.

\section{Results}

\section{$U-P b$ mineral data}

The results for the $\mathrm{U}-\mathrm{Pb}$ analyses on mineral separates are summarized in Table 1 and in Fig. 2.

A1085-Halmejärvi. The pale brown translucent zircons are typically magmatic: the tetrahedral prisms are terminated by simple pyramid faces. The L/B (length to breadth) ratio varies from 1.5 to 3 . Inclusions are virtually absent. The discordancy pattern is normal, i.e. the abraded fraction is the most concordant one while the discordance of the other fractions increases as they become lighter and more metamict with increasing uranium content (Fig. 2a). The age of the upper intercept, $2745 \pm 8 \mathrm{Ma}$, can be regarded as the crystal-

Table 1. U-Pb mineral data from the Puukari map sheet area.

\begin{tabular}{|c|c|c|c|c|c|c|c|c|c|c|}
\hline \multirow[t]{2}{*}{ Sample } & \multirow[t]{2}{*}{ Fraction } & \multirow{2}{*}{$\begin{array}{c}\text { Uconc } \\
\text { ppm }\end{array}$} & \multirow{2}{*}{$\begin{array}{c}\text { Pbconc } \\
\text { ppm }\end{array}$} & \multirow{2}{*}{$\begin{array}{c}\text { 206/204 } \\
\text { meas. }\end{array}$} & \multirow{2}{*}{$\begin{array}{r}206 / 238 \\
\text { Corr }\end{array}$} & \multirow{2}{*}{$\begin{array}{l}207 / 235 \\
\text { ected for b }\end{array}$} & \multirow{2}{*}{$\begin{array}{l}207 / 206 \\
\text { ank }\end{array}$} & \multicolumn{3}{|c|}{ Apparent age in $\mathrm{Ma}$} \\
\hline & & & & & & & & $6 / 8$ & $7 / 5$ & $7 / 6$ \\
\hline \multicolumn{11}{|c|}{ A1085-Halmejärvi } \\
\hline A $1085 \mathrm{~A}$ & $+4.5 / \mathrm{abr}$ & 210.6 & 121.66 & 8112 & .5181 & 13.60 & .1904 & 2691 & 2722 & 2745 \\
\hline B & +4.5 & 204.3 & 113.33 & 76000 & .5069 & 13.18 & .1887 & 2643 & 2692 & 2730 \\
\hline $\mathrm{C}$ & $4.3-4.5$ & 393.7 & 205.21 & 13790 & .4699 & 12.16 & .1877 & 2483 & 2616 & 2722 \\
\hline $\mathrm{D}$ & $4.2-4.3$ & 660.5 & 302.51 & 7700 & .4134 & 10.51 & .1844 & 2230 & 2480 & 2692 \\
\hline $\mathrm{E}$ & tit/dark & 104.5 & 57.47 & 1788 & .4689 & 11.30 & .1748 & 2478 & 2548 & 2604 \\
\hline $\mathrm{F}$ & tit & 14.98 & 8.70 & 219 & .4570 & 8.61 & .1502 & 2241 & 2297 & 2348 \\
\hline \multicolumn{11}{|c|}{ A1086-Haasiavaara } \\
\hline \multicolumn{2}{|c|}{$\mathrm{A} 1086 \mathrm{~A}+4.5 / \mathrm{abr}$} & 166.3 & 100.20 & 3480 & .5208 & 14.34 & .1997 & 2702 & 2772 & 2823 \\
\hline B & +4.5 & 190.3 & 108.04 & 4525 & .4977 & 13.63 & .1987 & 2604 & 2724 & 2815 \\
\hline $\mathrm{C}$ & $4.3-4.5$ & 340.2 & 163.35 & 1797 & .4153 & 11.12 & .1942 & 2239 & 2533 & 2777 \\
\hline $\mathrm{D}$ & $4.2-4.3$ & 692.6 & 268.15 & 964 & .3261 & 8.44 & .1820 & 1819 & 2279 & 2721 \\
\hline $\mathrm{E}$ & tit & 2.6 & 1.14 & 91.8 & .4989 & 12.66 & .1841 & 2609 & 2654 & 2690 \\
\hline $\mathrm{bA}$ & $+4.5 / \mathrm{abr}$ & 167.0 & 100.34 & 4133 & .5258 & 14.45 & .1993 & 2723 & 2779 & 2820 \\
\hline $\mathrm{bB}$ & +4.5 & 170.2 & 101.72 & 3837 & .5209 & 14.31 & .1993 & 2703 & 2770 & 2820 \\
\hline
\end{tabular}


Table 1. (continued)

\begin{tabular}{|c|c|c|c|c|c|c|c|c|c|c|}
\hline \multirow[t]{2}{*}{ Sample } & \multirow[t]{2}{*}{ Fraction } & \multirow{2}{*}{$\begin{array}{l}\text { Uconc } \\
\text { ppm }\end{array}$} & \multirow{2}{*}{$\begin{array}{c}\text { Pbconc } \\
\text { ppm }\end{array}$} & \multirow{2}{*}{$\begin{array}{c}206 / 204 \\
\text { meas. }\end{array}$} & \multirow{2}{*}{$\begin{array}{r}\text { 206/238 } \\
\text { Corr }\end{array}$} & \multirow{2}{*}{$\begin{array}{l}207 / 235 \\
\text { cted for b }\end{array}$} & \multirow{2}{*}{$\begin{array}{l}\text { 207/206 } \\
\text { ank }\end{array}$} & \multicolumn{3}{|c|}{ Apparent age in $\mathrm{Ma}$} \\
\hline & & & & & & & & $6 / 8$ & $7 / 5$ & $7 / 6$ \\
\hline \multicolumn{11}{|c|}{ A1087-Aittolanaho } \\
\hline A1087A & $4.3-4.5$ & 483.0 & 226.32 & 2550 & .3935 & 9.87 & .1820 & 2139 & 2422 & 2671 \\
\hline B & $4.3-4.5$ & 547.9 & 262.42 & 3472 & .4092 & 10.29 & .1823 & 2211 & 2460 & 2674 \\
\hline $\mathrm{C}$ & $4.0-4.2$ & 1121.0 & 494.60 & 2543 & .3701 & 8.90 & .1745 & 2029 & 2328 & 2601 \\
\hline D & $4.3-4.5$ & 678.7 & 211.38 & 3826 & .2663 & 6.70 & .1825 & 1521 & 2072 & 2675 \\
\hline E & $4.0-4.2$ & 996.1 & 421.30 & 2981 & .3560 & 8.85 & .1804 & 1963 & 2322 & 2656 \\
\hline $\mathrm{F}$ & tit & 161.8 & 251.68 & 97.4 & .5107 & 10.85 & .1541 & 2659 & 2510 & 2392 \\
\hline G & $4.3-4.5 / 1$ & 731.0 & 347.71 & 517 & .3627 & 9.01 & .1803 & 1994 & 2339 & 2655 \\
\hline $\mathrm{H}$ & $4.3-4.5 / \mathrm{r}$ & 117.8 & 65.08 & 9628 & .4504 & 11.61 & .1870 & 2397 & 2573 & 2715 \\
\hline I & $4.0-4.2$ & 1241.6 & 586.51 & 4531 & .4014 & 9.46 & .1709 & 2175 & 2383 & 2566 \\
\hline $\mathrm{J}$ & tit/abr & 146.2 & 180.99 & 145 & .4934 & 10.92 & .1605 & 2585 & 2516 & 2460 \\
\hline \multicolumn{11}{|c|}{ A1088-Vetelänvaara } \\
\hline A1088A & $+4.5 / \mathrm{abr}$ & 148.8 & 68.54 & 16790 & .3985 & 10.50 & .1911 & 2162 & 2479 & 2751 \\
\hline B & +4.5 & 251.1 & 99.51 & 4148 & .3426 & 8.87 & .1877 & 1899 & 2324 & 2722 \\
\hline $\mathrm{C}$ & $4.3-4.5$ & 308.3 & 150.36 & 369 & .3831 & 9.73 & .1844 & 2090 & 2410 & 2692 \\
\hline D & $4.2-4.3$ & 517.4 & 167.54 & 376 & .3743 & 9.30 & .1801 & 2049 & 2367 & 2654 \\
\hline E & +4.5/long & 185.1 & 94.88 & 13305 & .4476 & 11.58 & .1877 & 2384 & 2571 & 2722 \\
\hline $\mathrm{F}$ & 4.3-4.5/long & 276.9 & 132.98 & 4305 & .4282 & 10.91 & .1848 & 2297 & 2515 & 2696 \\
\hline G & $+4.5 /$ round & 207.6 & 101.89 & 9342 & .4322 & 11.22 & .1882 & 2315 & 2541 & 2727 \\
\hline $\mathrm{H}$ & $4.3-4.5 / \mathrm{rd}$ & 305.6 & 140.25 & 9101 & .4150 & 10.58 & .1849 & 2237 & 2487 & 2697 \\
\hline \multicolumn{11}{|c|}{ A1089-Huuskonvaara } \\
\hline A1089A & 4.3 & 188.8 & 97.33 & 3084 & .4635 & 12.30 & .1925 & 2454 & 2627 & 2763 \\
\hline B & $4.2-4.3$ & 646.4 & 243.99 & 5735 & .3548 & 8.85 & .1808 & 1957 & 2322 & 2661 \\
\hline $\mathrm{C}$ & $4.0-4.2$ & 863.0 & 284.54 & 4595 & .3140 & 7.60 & .1755 & 1760 & 2184 & 2611 \\
\hline \multicolumn{11}{|c|}{ A1128-Rasimäki } \\
\hline A1128A & $+4.5 / \mathrm{abr}$ & 177.9 & 89.17 & 571 & .3692 & 7.51 & .1475 & 2025 & 2173 & 2316 \\
\hline $\mathrm{B}$ & +4.5 & 268.6 & 86.80 & 691 & .2515 & 4.95 & .1426 & 1446 & 1810 & 2259 \\
\hline $\mathrm{C}$ & $4.3-4.5$ & 435.5 & 132.73 & 679 & .2452 & 4.82 & .1426 & 1413 & 1788 & 2259 \\
\hline $\mathrm{D}$ & $4.2-4.3$ & 676.2 & 201.57 & 666 & .2398 & 4.74 & .1433 & 1385 & 1773 & 2267 \\
\hline $\mathrm{E}$ & $4.0-4.2$ & 1083.6 & 302.38 & 894 & .2307 & 4.47 & .1405 & 1338 & 1725 & 2233 \\
\hline $\mathrm{F}$ & $4.2-4.3 / \mathrm{a}$ & 615.8 & 257.23 & 4276 & .3606 & 7.42 & .1493 & 1984 & 2163 & 2338 \\
\hline \multicolumn{11}{|c|}{ A1136-Halmejärvi } \\
\hline A1136A & $4.3-4.5$ & 296.6 & 170.99 & 4626 & .4905 & 12.28 & .1815 & 2572 & 2625 & 2667 \\
\hline B & $4.2-4.3$ & 395.8 & 231.95 & 3828 & .4735 & 11.76 & .1802 & 2498 & 2585 & 2654 \\
\hline C & $4.2-4.3$ & 457.4 & 262.79 & 2543 & .4605 & 11.37 & .1792 & 2441 & 2554 & 2645 \\
\hline D & tit/abr & 63.0 & 63.73 & 843 & .4958 & 12.31 & .1801 & 2595 & 2628 & 2654 \\
\hline \multicolumn{11}{|c|}{ A1137-Riihikangas } \\
\hline A1137A & +4.2 & 545.9 & 229.12 & 2307 & .3734 & 8.52 & .1654 & 2045 & 2287 & 2511 \\
\hline B & $3.6-4.2$ & 1185.2 & 436.97 & 1897 & .3333 & 7.38 & .1607 & 1854 & 2159 & 2463 \\
\hline \multicolumn{11}{|c|}{ A1138-Mustalaissuo } \\
\hline A1138A & +4.3 & 443.6 & 229.30 & 5235 & .4234 & 10.40 & .1781 & 2276 & 2470 & 2635 \\
\hline B & $4.2-4.3$ & 621.8 & 264.53 & 5674 & .3954 & 9.77 & .1791 & 2147 & 2412 & 2645 \\
\hline $\mathrm{C}$ & $4.0-4.2$ & 803.6 & 333.28 & 4407 & .3887 & 9.48 & .1768 & 2116 & 2385 & 2623 \\
\hline D & $3.6-4.0$ & 986.9 & 382.87 & 3158 & .3636 & 8.80 & .1756 & 1999 & 2317 & 2611 \\
\hline \multicolumn{11}{|c|}{ A1139-Tornikangas } \\
\hline A1139A & $4.3-4.5 / \mathrm{a}$ & 330.0 & 189.96 & 2218 & .5078 & 13.23 & .1889 & 2647 & 2695 & 2732 \\
\hline B & $4.3-4.5$ & 546.7 & 267.50 & 1295 & .4359 & 10.90 & .1814 & 2332 & 2514 & 2665 \\
\hline $\mathrm{C}$ & $4.2-4.3$ & 685.8 & 325.66 & 1239 & .4235 & 10.54 & .1805 & 2276 & 2483 & 2657 \\
\hline D & $4.0-4.2$ & 808.5 & 382.94 & 842 & .4147 & 10.26 & .1794 & 2236 & 2458 & 2647 \\
\hline
\end{tabular}

Concentrations in ppm; corrected for blank.

Common lead corrections: 6/4: 13.42; 7/4: 14.65; 8/4: 33.14

A1087E: 6/4: 13.60; 7/4: 14.86; 8/4: 33.44 

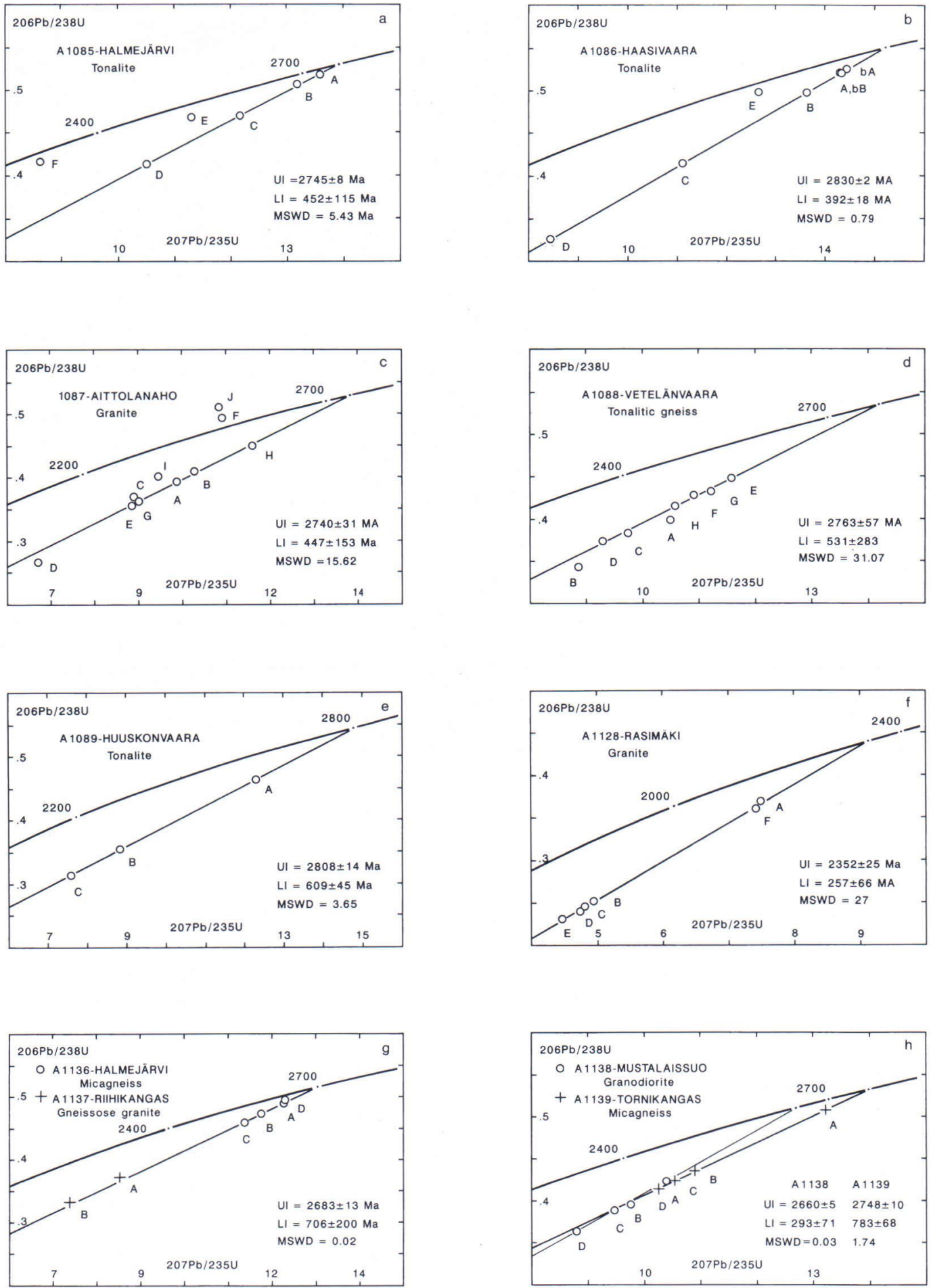

Fig. 2. U-Pb mineral results from the Puukari map sheet area on concordia diagrams. Note that the axis dimensions vary from one diagram to the next. 
Fig. 3. A back-scattered electron image of a zircon crystal from sample A1087-Aittolanaho displaying zones of xenotime-zircon solid solution.

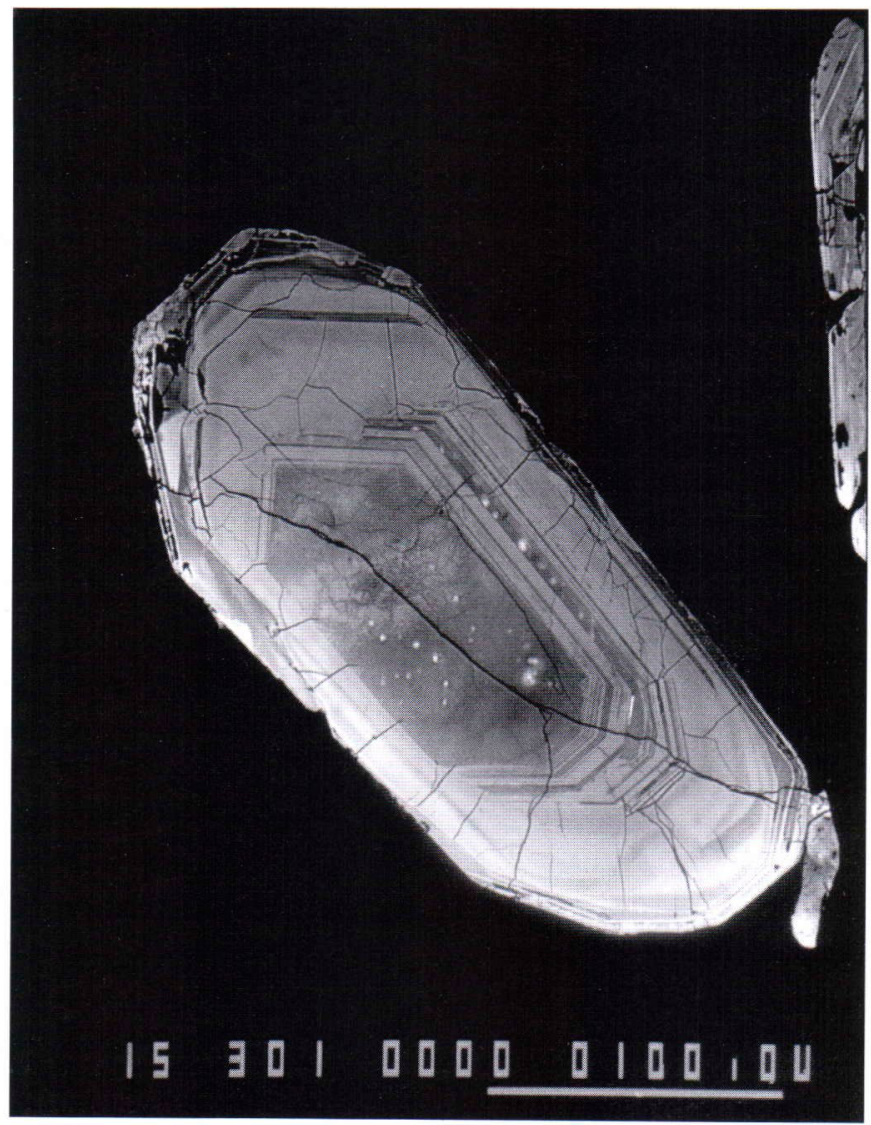

lization age of the zircons. The geologically meaningless lower intercept age, $455 \pm 120 \mathrm{Ma}$, falls in the 300-700 Ma range typical for most Finnish Precambrian rocks. The two titanite fractions, picked apart using colour as a criterion, are of different ages and have very different common lead contents. The age relationship is correct, as the younger pale brown crystals contain inclusions of the older dark brown titanite.

A1086-Haasiavaara. The morphology of the pale brown zircons is magmatic and the discordancy pattern is normal (Fig. 2b). The crystals are usually zoned, and there is no change in chemical composition. In some rare cases, there occur unzoned cores with the same chemistry as the rest of the crystals. The upper intercept age, $2830 \pm 2$ $\mathrm{Ma}$, may be interpreted as a crystallization age. The lower intercept is $393 \pm 18 \mathrm{Ma}$. The titanite has a very low $\mathrm{U}$ content and registers a ${ }^{207} \mathrm{~Pb} /{ }^{206} \mathrm{~Pb}$ age of $2690 \mathrm{Ma}$.

A1087-Aittolanaho. The zircons are morphologically variable, turbid, reddish brown crystals. Especially in the coarse fractions $(+150 \mu \mathrm{m})$ the crystals are almost round because of the abundant high-index surfaces. In the finer fractions the crystals are more zircon-like with an L/B of 1.5-2.5, but even these exhibit high-index prismatic and pyramidal surfaces. Electron microprobe data demonstrate that there are darker, often discontinuous zones in the zircons which can contain up to $10 \% \mathrm{Y}$ and $\mathrm{Ce}$ oxides and are lower in $\mathrm{SiO}_{2}$ than stochiometric zircon (Fig. 3). These zones consist most likely of a solid solution of the isomorphic minerals zircon and xenotime. The titanite is anhedral, which may be a result of milling. The analyses yield an abnormal distribution 


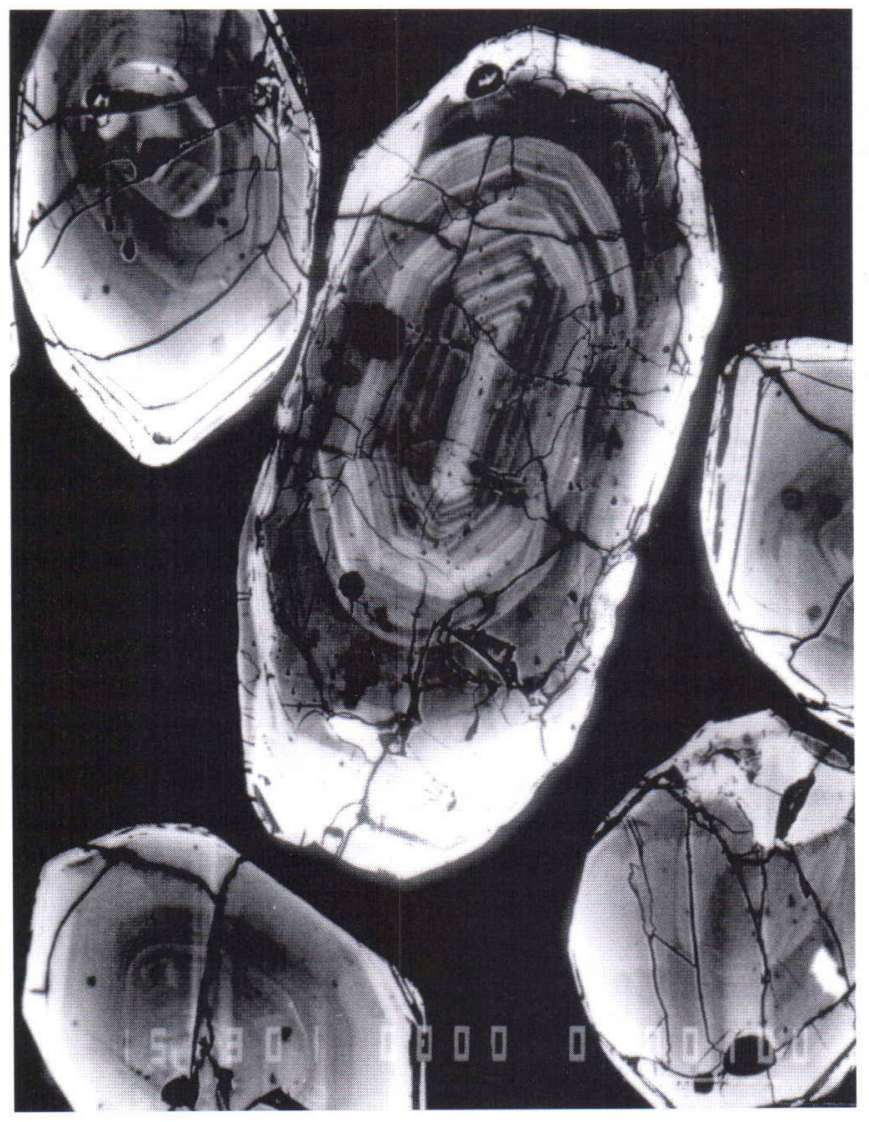

Fig. 4. A back-scattered electron image of an outwardly euhedral zircon from sample A1088-Vetelänvaara containing a wellrounded zoned core. Note that the core boundaries cross-cut the zonation.
(Fig. 2c). The discordance and uranium contents do not correlate, and while the abraded fraction (D) is most discordant within the population, the residue of the acid leach experiment $(\mathrm{H})$ is least discordant. On the concordia diagram it is evident that the samples do not form a coherent pattern. The fractions A, B, E, G and $\mathrm{H}$ form a linear trend with an upper intercept age of $2740 \pm 31 \mathrm{Ma}$ and the lower intercept at $447 \pm 153 \mathrm{Ma}$. The other zircon fractions (C, D and I) form a linear trend with an upper intercept age of $2538 \pm 9 \mathrm{Ma}$, but the lower intercept is negative. The two titanites are rich in common lead and thus the common lead correction influences the result significantly. The least radiogenic lead that can be reasonably used is that of the Taivaljärvi deposit. This gives a ${ }^{207} \mathrm{~Pb} /{ }^{206} \mathrm{~Pb}$ age of $2460 \mathrm{Ma}$ for the abraded fraction J, which is a maximum estimate for the last resetting of the titanite $\mathrm{U}-\mathrm{Pb}$ system.
A1088-Vetelänvaara. Most of the zircons of this sample are light brown and about $90 \%$ of them are roundish due to high-index crystal faces. Only $10 \%$ of the crystals are prismatic with an L/B ratio of $3-4$. About $15 \%$ of the roundish zircons are reddish in colour. Electron microprobe work shows that the zircons are heterogeneous. In extreme cases (Fig. 4), prismatic crystals can contain a well zoned rounded core, the zonation of which is cut by the rounded surface. Outside, there occurs a faintly zoned area, coated by a strongly reflecting material. Measurements on the chemical composition of the zircon show that the $\mathrm{HfO}_{2}$ content of the crystal increases from 1.5 to $2 \%$ on the border of the two outer rims. Most of the rounded crystals do not contain a zoned core, resemble the faintly zoned grey area of the composite prisms and also have a similar $\mathrm{HfO}_{2}$ content.

The discordancy pattern of the analysed frac- 
tions is abnormal and they do not form a coherent linear trend (Fig. 2d). If all of the data is included in the age calculation, the upper intercept gives an age of $2763 \pm 57 \mathrm{Ma}$, with the lower intercept at $531 \pm 283 \mathrm{Ma}$. By excluding fractions A, $\mathrm{B}$ and $\mathrm{G}$ the upper intercept age becomes $2770 \pm 38$ Ma.

A1089-Huuskonvaara. The zircons are pale brown prisms terminated by low-index pyramid faces. The $\mathrm{L} / \mathrm{B}$ of the crystals ranges from 2.5 to 3.5. The three zircon fractions exhibit a normal discordancy pattern with upper and lower intercepts of $2808 \pm 14$ and $609 \pm 45 \mathrm{Ma}$ (Fig. 2e). If the upper intercept of the discordia for A1086 is included in the calculation, the age estimates become $2826 \pm 14$ and $666 \pm 64 \mathrm{Ma}$.

A1128-Rasimäki. The zircons are brown, stubby prisms (L/B 1.5-3) and usually have very sharp edges and exhibit occasional zonation. Their discordancy pattern is normal, except for fraction F, which is a relatively light population abraded for 6 hours (Fig. 2f). It is almost as concordant as the abraded heavy fraction (A), but in contrast to the other zircons it contains much less common lead, as is shown by its ${ }^{206} \mathrm{~Pb} /{ }^{204} \mathrm{~Pb}$ ratio. Electron microprobe studies indicate that the lighter zircon fractions contain corroded zones, which have probably been removed by the prolonged air abrasion of fraction $\mathrm{F}$. The upper intercept age estimate, $2352 \pm 25 \mathrm{Ma}$, is determined by the two abraded fractions. The corresponding lower intercept is $257 \pm 66 \mathrm{Ma}$. Omitting fraction A or, alternatively, $\mathrm{F}$ from the calculation gives estimates of $2371 \pm 25$ or $2337 \pm 26 \mathrm{Ma}$, respectively. If both abraded fractions are excluded from the calculation, the result is $2467 \mathrm{Ma}$, but the error estimate is very high $(+322,-191 \mathrm{Ma})$ because of the small dispersion of populations B-E on the concordia diagram.

A1136-Halmejärvi. The three zircon fractions represent smallish, pale brown, almost euhedral zircons with an L/B ratio from 1.5 to 3 . They are generally slightly zoned, and sometimes have narrow outer rims enriched in $\mathrm{HfO}_{2}$. The discordancy pattern is normal, and the upper intercept age of $2683 \pm 13 \mathrm{Ma}$ is well defined (Fig. $2 \mathrm{~g}$ ), the rather large error arising from the limited dispersion of the analysed zircons. The lower intercept is $706 \pm 200 \mathrm{Ma}$. The titanite fraction is slightly discordant and marginally younger than the zircons.

A1137-Riihikangas. The two relatively discordant zircon fractions consist of brownish euhedral crystals. If a line is drawn through the two points, the upper intercept is $2605 \mathrm{Ma}$ (Fig. 2g).

A1138-Mustalaissuo. The pale brown zircons are typically magmatic with an L/B of 2-3 and a normal discordancy pattern. The upper intercept age is $2673 \pm 68 \mathrm{Ma}$, which improves to $2660 \pm 5$ if the deviating fraction $\mathrm{B}$ is excluded from the calculation (Fig. 2h).

A1139-Tornikangas. The brownish, finegrained zircons are mainly euhedral with a simple geometry and an L/B of 2-3. The discordancy pattern is normal, and although the upper intercept age of $2748 \pm 10 \mathrm{Ma}$ (Fig. 2h) is largely determined by the abraded fraction (A), the other three fractions give a result of $2715 \pm 20 \mathrm{Ma}$, which suggests that all four fractions form a coherent population. The lower intercept, $783 \pm 68$ $\mathrm{Ma}$, is slightly high.

\section{Whole rock $U-P b$ analyses}

The whole rock $\mathrm{U}-\mathrm{Pb}$ analyses (Table 2, Fig. 5) exhibit a considerable scatter. When the uranogenic leads are considered, only six of ten samples plot in the vicinity of the linear trend determined by the metavolcanic rocks of the Tipasjärvi greenstone sequence and, of these, only four (the stromatic migmatites A1086-Haasiavaara and A1089-Huuskonvaara, the granite dyke A1137Riihikangas as well as the granodiorite A1138Mustalaissuo) are Archaean granitoids. When the thorogenic isotope ${ }^{208} \mathrm{~Pb}$ is added to the consideration, none of the samples plot on the greenstone trend.

A noteworthy feature of the data are the low uranium contents of most of the samples. This is probably due to a secondary process, as only the Palaeoproterozoic sample A1128 yields a reasonable age- and U-corrected lead isotopic composition. On the other hand, the high contents of thorogenic lead in some of the samples indicate that radiogenic lead evolved over a considerable period 
Table 2. U-Pb analyses of whole rocks from the Punkari map sheet.

\begin{tabular}{lllrcrc}
\hline \multirow{2}{*}{ Sample } & & \multicolumn{2}{c}{ Concentrations } & Lead ratios & & \\
& & $\mathrm{U}$ & $\mathrm{Pb}($ tot $)$ & $206 / 204$ & $207 / 204$ & $208 / 204$ \\
\hline A1085 & Tonalite & 0.43 & 8.55 & 17.137 & 15.628 & 35.247 \\
A1086 & Tonalite & 0.62 & 6.30 & 17.756 & 15.535 & 35.664 \\
A1087 & Granite & 2.16 & 18.34 & 17.503 & 15.598 & 46.279 \\
A1088 & Tonalitic gneiss & 0.57 & 7.28 & 17.170 & 15.624 & 37.566 \\
A1089 & Tonalite & 0.82 & 6.16 & 17.862 & 15.540 & 35.712 \\
A1128 & Granite & 4.06 & 33.24 & 17.136 & 15.375 & 37.917 \\
A1136 & Mica schist & 3.36 & 11.09 & 19.642 & 15.999 & 54.439 \\
A1137 & Granite gneiss & 4.38 & 32.30 & 18.883 & 15.701 & 43.055 \\
A1138 & Granodiorite & 1.11 & 7.97 & 20.027 & 15.974 & 38.693 \\
A1139 & Mica gneiss & 0.67 & 12.37 & 16.098 & 15.241 & 35.927 \\
\hline
\end{tabular}

Concentrations in ppm.
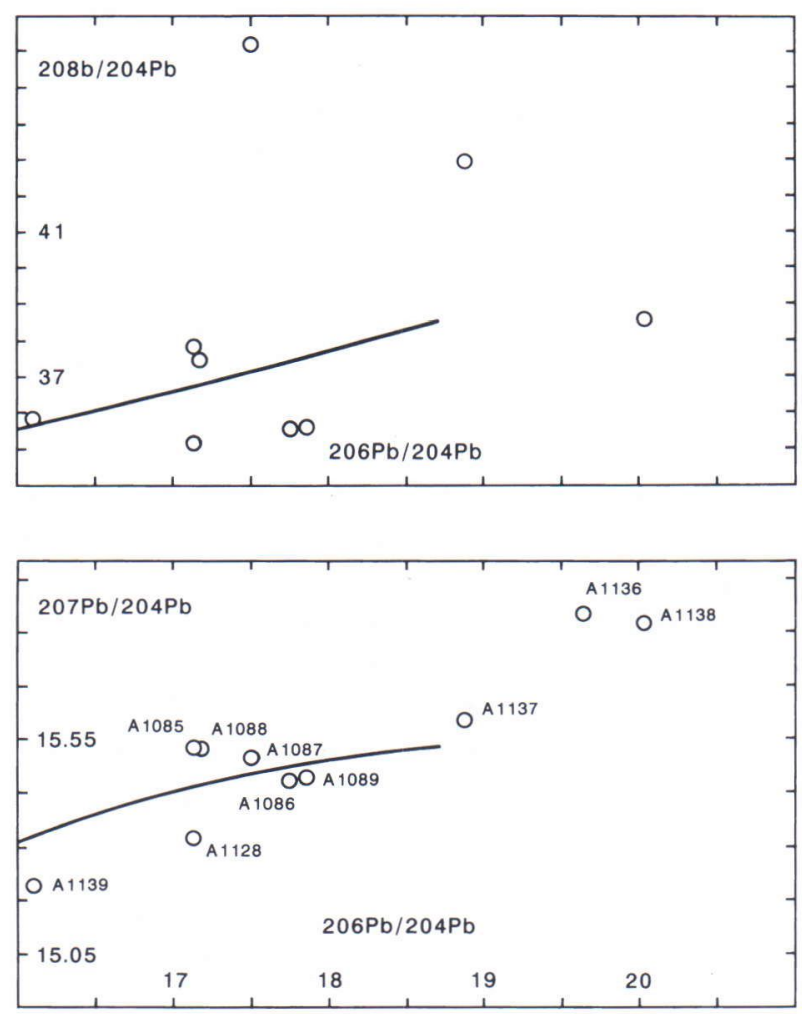

Fig. 5. Results of common lead analyses from the samples from the Puukari map sheet area. The two-stage evolution curve of Stacey and Kramers (1975) is shown for reference.

of time, and thus the apparent loss of uranium either occurred recently, or there was an early, perhaps Palaeoproterozoic $(1.9 \mathrm{Ga})$, flux of external thorium into some of the rocks sampled.

Taken together, the lead isotopic data indicate that the two oldest granitoids (A1086 and A1089) may stem from a similar source, while the other rocks exhibit a considerable scatter. Against this background, it seems that Vidal et al. (1980) were extremely lucky in their sampling as most of their analyses, irrespective of rock type, plotted on a single trend for uranogenic leads. 


\section{Interpretation}

At first sight, the granitoid rocks yield a confusing age picture: they all have different zircon upper intercept ages and the whole rock data suggest several different sources. Two of them, A1087 and A1088, contain heterogeneous zircon populations. The only rock giving a result directly supported by field evidence is granite A1128, which clearly intrudes the basement gneiss complex. However, the ages of A1086 (2832 $\pm 2 \mathrm{Ma})$, A1085 (2745 $\pm 8 \mathrm{Ma})$ and A1138 (2660 $\pm 5 \mathrm{Ma})$ agree with observations from other localities.

Luukkonen (1985) reports a U-Pb zircon age of $2843 \pm 18 \mathrm{Ma}$ for the palaeosome of a migmatitic rock at Lylyvaara, and Martin et al. (1983) report a similar $\mathrm{Rb}-\mathrm{Sr}$ whole rock age for the grey gneisses at Kivijärvi. Sample A1089 (2808 14 Ma) may also be a product of the $2.83 \mathrm{Ga}$ event, since the error is only marginally increased when forcing it to pass within analytical error through the 2830 Ma point of the concordia curve.

The $2.75 \mathrm{Ga}$ event, represented by A1085, has been recorded from a quartz diorite dyke crosscutting the Kuhmo-Suomussalmi greenstone belt (Hyppönen 1983) and granitoids in the Ilomantsi region are 2.73-2.74 Ga old (Wetherill et al. 1962, Pekkarinen 1979, Vaasjoki et al. 1993).

Many zircon and titanite ages from the Finnish Archaean are from 2.70 to $2.65 \mathrm{Ga}$ (Wetherill et al. 1962, Kouvo \& Tilton 1966, Hyppönen 1983, Vaasjoki et al. 1993). They are represented in our material by sample A1138 (2660 $\pm 5 \mathrm{Ma})$. Moreover, the results for A1138 and A1139 (2660 \pm 5 and $2748 \pm 10 \mathrm{Ma}$ ) are consistent with each other, as the former is a granodiorite cross-cutting the mica gneisses represented by the latter. Thus the most likely provenance for the mica schists in the Puukari map sheet is the $2.75 \mathrm{Ga}$ continental crust, although the $2.79 \mathrm{Ga}$ volcanic rocks may have been local contributors. The variation in the common lead data for these samples is consistent with this hypothesis and particularly the ${ }^{208} \mathrm{~Pb}$ data suggest variable fractionation of $\mathrm{U}$ and $\mathrm{Th}$ during the erosional/depositional processes. As titanites from the older magmatic rocks (A1085 and A1086) are under $2.7 \mathrm{Ga}$ old, it may be argued that the $2.66 \mathrm{Ga}$ magmatism also resulted in a regional thermal event exceeding $500^{\circ} \mathrm{C}$, which may be related to the Archaean $\mathrm{D}_{4}$ deformation also noted in other areas (Luukkonen 1988 and 1992).

Accepting the $2.75 \mathrm{Ga}$ event as a major magmatic episode helps to attempt interpretations of the heterogeneous zircons from samples A1087 and A1088. If the fractions A, B and G are excluded from the calculation for the tonalitic gneiss A1088, the upper intercept becomes $2770 \pm 38 \mathrm{Ma}$, and the rejected fractions plot below the best-fitting line. A noteworthy feature is that A1088A is the abraded fraction, from which the outer rims have been removed and thus represents mainly the cores of the zircons. Fig. 4 demonstrates that the cores in the larger, apparently euhedral zircons are well-rounded and may well be older than the 2.75 Ga event. Thus A1088 is a paragneiss containing older material reworked during the $2.75 \mathrm{Ga}$ episode, with some of the zircons only partially reset. This thesis is to some degree supported by the common lead data, as A1088 contains a high proportion of ${ }^{207} \mathrm{~Pb}$, which may be interpreted as indicating a prolonged residence in a source with an elevated $\mathrm{U} / \mathrm{Pb}$ ratio, e.g. the continental crust.

If the $2.75 \mathrm{Ga}$ event is taken as an anchorpoint for the granite A1087, the interpretation is quite the opposite. The titanite data (A1087F and A1087J) show that the rock was at a temperature of $>500^{\circ} \mathrm{C}$ at about $2.4 \mathrm{Ga}$. Because of the high common lead contents of the titanites, this estimate depends on the values used for the common lead correction, but reasonable compositions yield ${ }^{207} \mathrm{~Pb} /{ }^{206} \mathrm{~Pb}$ ages in the $2350-2460 \mathrm{Ma}$ range. On the other hand, if the titanites and the zircon fractions C, D and I are excluded from the calculation, the upper intercept for the remaining samples is $2746 \pm 20 \mathrm{Ma}$. One may thus argue that most of the zircons contained in the granite vein were formed during the $2.75 \mathrm{Ga}$ magmatic episode. The present vein was, however, formed later, perhaps during the intrusion of the $2.35 \mathrm{Ga}$ granites. Thus the zircons of the vein would be mainly inherited, and the fact that they are not reset indicates that the granitizing fluids intruded the wall rock at $<750^{\circ} \mathrm{C}$ (cf. Vaasjoki \& Sakko 1988). As the abraded fraction D plots below the best- 
fitting line, the protolith may have contained also some $2.84 \mathrm{Ga}$ old material. A relatively long crustal residence time is supported by the relatively high ${ }^{207} \mathrm{~Pb}$ contents, while the very high amount of ${ }^{208} \mathrm{~Pb}$ suggests that either a large part of $U$ was removed from the rock, or a substantial amount of Th was added to it, very early in its history. The fact that both titanites are extremely enriched in ${ }^{208} \mathrm{~Pb}$ favours the latter alternative and suggests that the addition of Th probably occurred during the ca. $2.4 \mathrm{Ga}$ event.

The result from A1136 is enigmatic: the material comes from inclusions occurring in a rock looking similar to, and lying only $500 \mathrm{~m}$ from, the site of A1085, which has an age of $2745 \pm 8$ Ma. The zircons from the inclusions yield, however, an age of $2683 \pm 2 \mathrm{Ma}$, exhibit a normal discordancy pattern and are not particularly discordant. Moreover, ages under $2.7 \mathrm{Ga}$ are not uncommon elsewhere (Hyppönen 1983, Luukkonen 1985). Thus the result from A1136 may signify a later thermal event, causing a nearly total resetting of the zircons during the $2.66 \mathrm{Ga}$ magmatism. The relatively high radiogenic lead, and the very high proportion of ${ }^{208} \mathrm{~Pb}$ in the whole rock sample in particular, also supports the thesis of secondary effects on this sample.

It seems feasible to conclude that three pulses of Archaean granitoid magmatism occurred in the Puukari map sheet area: the oldest at $2.83 \mathrm{Ga}$, an intermediate one at $2.75 \mathrm{Ga}$ and the youngest at 2.66 Ga. The 2.66 Ga event could explain some "discrepancies" observed between various radiometric methods. Thus the ca. $2.65 \mathrm{Ga}$ results obtained for many granitoids using the $\mathrm{Rb}-\mathrm{Sr}$ and $\mathrm{Pb}$ $\mathrm{Pb}$ whole rock methods may well be a result of regional metamorphism and fluid circulation caused by the $2.66 \mathrm{Ga}$ intrusive event.

The intrusion of the Rasimäki granite (A1128) apparently occurred $2.35 \mathrm{Ga}$ ago. The very low ${ }^{207} \mathrm{~Pb}$ and the normal ${ }^{208} \mathrm{~Pb}$ contents of the whole rock sample are suggestive of a relatively long residence time in a source with a low $\mathrm{U} / \mathrm{Th}$ ratio which, according to common plumbotectonic interpretations (e.g. Zartman \& Haines 1988), could be the lower continental crust. Thus the formation of the Rasimäki-type granites would not have in- volved formation of new crust, but would have been the result of remobilization of previously formed Archaean crust.

Our interpretation of the Aittolanaho (A1087) zircon data, as well as the younger titanite generation in the Halmejärvi tonalite (A1085), suggest that the intrusion of the earliest Proterozoic granites was accompanied by hydrothermal activity which, however, did not affect all rocks in the Puukari map sheet area. This observation is compatible with the suggestion of Halliday et al. (1988) that the low Rb-Sr ages observed in some of the younger granitoids may be a result of widespread, low-temperature hydrothermal events.

\section{THE AGE AND GENESIS OF GREENSTONE BELT METAVOLCANIC ROCKS AND ASSOCIATED SULPHIDE MINERALISATION}

\section{The Taivaljärvi and Ala-Luoma sulphide occurrences}

Initial exploration-related studies of galenas from the Ala-Luoma and Taivaljärvi prospects within the felsic metavolcanic rocks of the KuhmoSuomussalmi greenstone belt revealed very different lead isotopic compositions. As both deposits were considered volcanogenic stratabound ores (Kopperoinen \& Tuokko 1988) and the initial ${ }^{87} \mathrm{Sr} /{ }^{86} \mathrm{Sr}$ ratio of the Luoma metavolcanics hosting the Ala-Luoma mineralisation is very high (Martin \& Quérré 1984), this posed an interesting problem relating to the genesis and geological history of the deposits. It was hoped that isotopic studies of the ores and their host rocks would shed light not only on their origin but also on the emplacement sequence and the evolution of the Kuhmo-Suomussalmi greenstone belt in general.

The Ala-Luoma and Taivaljärvi Ag-Zn-Pb occurrences lie in intermediate to felsic metavolcanic rocks of the Kuhmo-Suomussalmi greenstone belt. Both deposits display features thought to be characteristic of stratabound exhalative ore deposits: pyroclastic volcanic host rocks, metal zonation as well as mineralogical and geochemical alteration haloes around the ores. 
The Ala-Luoma occurrence (Kopperoinen \& Tuokko 1988) lies in the upper part of the Luoma Group, which consists mostly of andesitic rocks penetrated in the west by a $2.7 \mathrm{Ga}$ old granodiorite (Patchett et al. 1981). The age relationship is clear, as the latter rock contains partly melted Luoma metavolcanics. The Luoma Group is separated from the rocks of the Saarikylä Group by a mylonitized albite-sericite rock. On the basis of detailed outcrop observations, Engel and Dietz (1989) recognized an angular unconformity in the area and argued that the contact between the Luoma and Saarikylä Groups is tectonic.

The sulphide mineralisation at Ala-Luoma is conformable with the main layering of the metavolcanics and is capped by a thin layer of iron sulphides. The mineralisation consists of banded disseminations and fracture-filling veins of $\mathrm{Zn}-\mathrm{Pb}$ Fe sulphides with associated quartz-carbonate gangue.

The Taivaljärvi Ag- $\mathrm{Zn}-\mathrm{Pb}$ deposit (Kopperoinen \& Tuokko 1988, Papunen et al. 1990) occurs in the upper part of a hydrothermally altered pyroclastic metavolcanic pile representing the main phase of the felsic volcanism in the belt. The rocks belong to the Koivumäki formation consisting of felsic metatuffs with quartz phenocrysts in a finegrained matrix. The felsic rocks are overlain by intermediate metavolcanics, sulphide schists, tholeiites and komatiites (Taipale 1983).

The mineralisation surfaces in a $500 \mathrm{~m}$ long and $40 \mathrm{~m}$ wide suboutcrop and continues at a $65^{\circ} \mathrm{dip}$ at least to $500 \mathrm{~m}$ in depth. It consists of several 2-15 m thick layers and the whole mineralised sequence is about $100 \mathrm{~m}$ thick. The host rock is a quartz-sericite schist which is interpreted as a metamorphosed felsic tuff. According to the $\mathrm{SiO}_{2}$ content, they have originally been dacites and rhyolites. In the mineralisation and its immediate country rocks $\mathrm{K}_{2} \mathrm{O}$ increases while $\mathrm{Na}_{2} \mathrm{O}$ and $\mathrm{CaO}$ decrease especially in the hanging wall. The alteration of the chemical composition is interpreted as having been caused by the circulation of oreforming hydrothermal fluids (Papunen et al. 1990).

The deposit lies within an explosive volcanic centre indicated by coarse pyroclastic rocks and thick and extensive fragmentary rocks. The alter- ation represents the feeder zones for hydrothermal solutions, which precipitated disseminated and vein-type mineralisation in the upper part of the ash material. The stratiform facies is minor. The hydrothermal activity probably occurred after periods of explosive volcanism, which explains the cyclic occurrence of mineralised horizons. Although metamorphism caused local remobilization, primary mineralised layers can still be traced and there is no mobilization of the sulphide material into the barren hanging-wall rocks.

Pyrite is common throughout the strata, including the barren hanging-wall rocks. Silver minerals occur mainly in the upper ore lenses, and are associated with veins of quartz, carbonate and $\mathrm{Zn}$ $\mathrm{Pb}$ sulphides. The lower ore lenses are calc-silicate interlayers with sphalerite, pyrrhotite and chalcopyrite as the main ore minerals. The deposit contains $21 \mathrm{Mt}$ of mineralised rock, of which $3 \mathrm{Mt}$ average $1.1 \% \mathrm{Zn}, 0.6 \% \mathrm{~Pb}, 175 \mathrm{~g} / \mathrm{t} \mathrm{Ag}$ and $0.4 \mathrm{~g} / \mathrm{t} \mathrm{Au}$.

\section{Sample material and results}

Fourteen sulphide separates from ten samples, 16 whole rock samples from felsic metavolcanics and 5 samples from mafic metavolcanic rocks were analysed for their lead isotopic compositions. Zircons from two samples of felsic metavolcanic rocks hosting the ores at Taivaljärvi ( $\underline{\mathrm{A} 1174}$, 7399.05, 4453.20) and Ala-Luoma (A1191, $7242.76,4465.80)$ were analysed in an attempt to determine their time of extrusion. To resolve possible age differences between the Luoma and Saarikylä Groups, a meta-andesite representing the most felsic part of the Saarikylä Group (A1192, $7242.81,4466.72$ ) was also analysed for $\mathrm{U}-\mathrm{Pb}$ in zircon.

\section{Common lead}

The common lead results from the Taivaljärvi and Ala-Luoma areas are summarized in Tables 3-5 and in Figs. 6 and 7.

Taivaljärvi (Fig. 6). The lead isotopic compositions of four galenas are identical within experimental error and demonstrate, together with the 
Table 3. Lead isotopic compositions of ore minerals from the Taivaljärvi Ag-Zn-Pb deposit.

\begin{tabular}{llccc}
\hline Sample & Mineral & ${ }^{206} \mathrm{~Pb} /{ }^{204} \mathrm{~Pb}$ & ${ }^{207} \mathrm{~Pb} /{ }^{04} \mathrm{~Pb}$ & ${ }^{208} \mathrm{~Pb} /{ }^{204} \mathrm{~Pb}$ \\
\hline G339 & galena & 13.413 & 14.650 & 33.140 \\
G339 & pyrite & 13.413 & 14.641 & 33.070 \\
G339 & sphalerite & 13.438 & 14.677 & 33.198 \\
G339 & pyrrhotite & 13.905 & 14.726 & 33.541 \\
G402 & galena & 13.417 & 14.654 & 33.141 \\
G403 & galena & 13.398 & 14.659 & 33.150 \\
G404 & galena & 13.398 & 14.644 & 33.126 \\
A1174B & pyrrhotite & 13.818 & 14.747 & 33.437 \\
A1174C & pyrrhotite & 13.794 & 14.742 & 33.427 \\
A1174D & pyrrhotite & 13.971 & 14.799 & 33.602 \\
\hline
\end{tabular}

Table 4. Lead isotopic compositions of metavolcanic rocks from the Taivaljärvi area.

\begin{tabular}{lllll}
\hline Sample & Locality & \multicolumn{3}{c}{${ }^{206} \mathrm{~Pb} /{ }^{204} \mathrm{~Pb}{ }^{207} \mathrm{~Pb} /{ }^{204} \mathrm{~Pb}{ }^{208} \mathrm{~Pb} /{ }^{204} \mathrm{~Pb}$} \\
\hline 3197 & Vidal et al.1986 & 15.34 & 15.07 & 35.12 \\
3215 & Vidal et al.1986 & 19.34 & 15.78 & 39.96 \\
A1059 & Tipas 1 & 16.084 & 15.349 & 35.585 \\
A1060 & Tipas 2 & 15.276 & 15.079 & 34.967 \\
A1061 & Tipas 3 & 16.110 & 15.175 & 35.649 \\
A1062 & Tipas 4 & 16.088 & 15.189 & 35.933 \\
A1066A KR 107/158 m & 20.146 & 15.736 & 39.834 \\
A1066B & KR 104b/285 m & 24.545 & 16.282 & 46.551 \\
A1174A & VK/95 m & 14.969 & 14.962 & 34.955 \\
A1174B VK/383 m & 13.843 & 14.753 & 33.521 \\
A1174C & VK/485 m & 13.770 & 14.723 & 33.400 \\
A1174D VK/550 m & 14.444 & 14.847 & 34.186 \\
A1181A pillow centre & 15.260 & 15.027 & 34.647 \\
A1181B & pillow margin & 17.450 & 15.584 & 37.520 \\
\hline
\end{tabular}

pyrite and sphalerite analyses from sample G339, that the original lead isotopic composition of the ore-forming material was homogeneous. The slightly more radiogenic lead found in the pyrrhotites of G339 and A1174 can be accounted for by addition of radiogenic lead formed in situ since ore formation. The whole rock samples from the incline (A1174A-A1174D) and from three outcrops (A1060-A1062) representing relatively well-preserved felsic metavolcanic rocks form a linear trend which passes, within experimental error, through the galena lead isotopic composition point. One of the samples from the komatiitic volcanic rocks (A1181A) and two samples from Vidal et al. (1980) lie, within analytical error, on the trend defined by the felsic metavolcanic rocks.
Table 5. Lead isotopic compositions of galenas and whole rock samples from the Saarikylä prospect at AlaLuoma.

\begin{tabular}{|c|c|c|c|c|}
\hline Sample & Source & ${ }^{206} \mathrm{~Pb} /{ }^{204} \mathrm{~Pb}$ & ${ }^{07} \mathrm{~Pb} /{ }^{204} \mathrm{~Pb}$ & ${ }^{208} \mathrm{~Pb} /{ }^{204} \mathrm{~Pb}$ \\
\hline G033 & galena & 13.600 & 14.863 & 33.440 \\
\hline G305 & galena & 13.606 & 14.879 & 33.494 \\
\hline G333 & galena & 13.593 & 14.873 & 33.466 \\
\hline G306 & galena & 14.030 & 15.003 & 33.829 \\
\hline A1065A & KR $27 / 40 \mathrm{~m}$ & 20.290 & 16.093 & 39.736 \\
\hline A1065B & KR 27/103 m & 17.110 & 15.577 & 36.520 \\
\hline A1065C & KR $27 / 158 \mathrm{~m}$ & 20.153 & 15.744 & 39.868 \\
\hline A1065D & KR $27 / 178 \mathrm{~m}$ & 15.717 & 15.348 & 35.549 \\
\hline A1065E & KR $27 / 186 \mathrm{~m}$ & 16.286 & 15.449 & 35.755 \\
\hline 2943 & Vidal et al. & 15.43 & 15.12 & 35.34 \\
\hline 2940 & Vidal et al. & 15.21 & 15.04 & 34.87 \\
\hline 2797 & Vidal et al. & 21.90 & 16.28 & 41.99 \\
\hline 2795 & Vidal et al. & 22.42 & 16.34 & 39.84 \\
\hline A1179A & Alaluoma & 14.885 & 15.186 & 34.557 \\
\hline A1179B & Alaluoma & 15.474 & 15.290 & 35.154 \\
\hline A1179C & Alaluoma & 15.966 & 15.341 & 36.452 \\
\hline A1180A & Valkeainen & 18.110 & 15.627 & 38.088 \\
\hline A1180B & Valkeainen & 15.137 & 15.034 & 34.652 \\
\hline A1180C & Tenhola & 15.244 & 15.190 & 35.155 \\
\hline
\end{tabular}

Sample A1059 deviates clearly from the other whole rock samples because of its relatively high content of ${ }^{207} \mathrm{~Pb}$. It is strongly sheared, and thinsection observation indicates that it contains chlorite instead of biotite and that its epidote is yellowish, whereas epidote in the other Taivaljärvi samples is bluish. The drill core samples A1066A and $\mathrm{A} 1066 \mathrm{~B}$ differ from the other samples as they are relatively poor in radiogenic ${ }^{207} \mathrm{~Pb}$. Together with sample A1059 they form a trend which gives an age estimate of $1805 \pm 88 \mathrm{Ma}$. One sample representing komatiitic rocks plots off the general trend of the metavolcanics, which is probably a consequence of extensive alteration.

If all the data (14 whole rock samples, including those of Vidal et al. 1980) are used in the regression calculation together with the galena average, the result is $2321 \pm 255 \mathrm{Ma}$, which is geologically meaningless. Eliminating the problematic drill core samples, the extremely tectonized sample A1059 and the mafic rocks give an estimate of $2835 \pm 112$ Ma for the felsic rock samples. Including three mafic rocks (two from Vidal et al. 1986 and A1181A) in the regression yields $2744 \pm 70 \mathrm{Ma}$. 
Ala-Luoma (Fig. 7). The analyses from this area exhibit considerable scatter. There is a definite difference between the rocks from the Luoma and Saarikylä Groups. The former plot in general above the evolution curve of Stacey and Kramers (1975) and when two samples (A1065C drill core logged as a felsic interlayer, but which may be a vein, and 2795 of Vidal et al. 1980) are omitted from the calculation, the result for the Luoma Group becomes $2436 \pm 80$ Ma. The Saarikylä Group samples (with the altered A1180C omitted), on the other hand, define a linear trend yielding an age estimate of $2726 \pm 24 \mathrm{Ma}$. The regression is, however, largely dependent on the highly radiogenic A1192. It is thus evident that, irrespective of what processes these ages signify, the geological evolution of the Luoma and Saarikylä Groups must have differed a great deal from each other. Also, the galena isotopic compositions from the Ala-Luoma sulphide occurrence do not plot on either the Luoma or the Saarikylä trends, but appear to be exotic to the environment.

\section{Comparisons}

When the data from the Taivaljärvi and Ala-Luoma areas are compared, it becomes evident that the samples from the Luoma Group deviate from the other samples of the Kuhmo-Suomussalmi greenstone belt. The samples from the Saarikylä Group are similar to both the felsic and mafic rocks at Taivaljärvi, and it seems that the angular contact at Ala-Luoma is indeed tectonic, separating two Archaean blocks with different histories. Another major difference is that while the isotopic data favour a volcanogenic origin of the ore at Taivaljärvi, they preclude at Ala-Luoma any connection between the ore and the metavolcanic rocks of either the Luoma or the Saarikylä Groups.

\section{$\mathrm{U}-\mathrm{Pb}$ on zircon}

The U-Pb analytical data on zircon for the Taivaljärvi and Ala-Luoma areas are summarized in Table 6 and in Fig. 8.

The four analysed fractions from the felsic metavolcanic rock hosting the Taivaljärvi Ag-Zn-

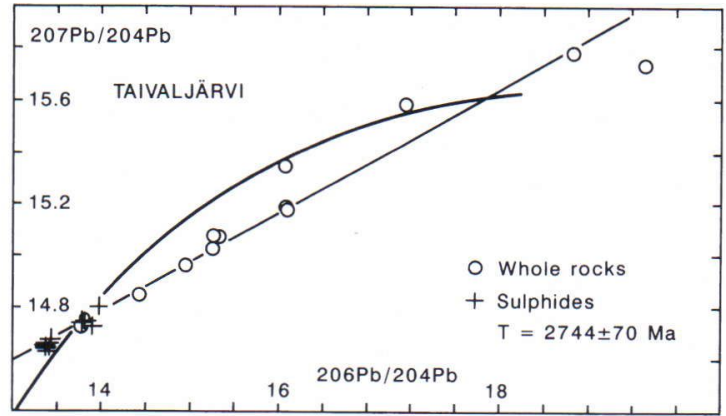

Fig. 6. Results of common lead analyses from the Taivaljärvi Ag-Zn deposit. Note that the sulphide leads plot on the extension of the linear trend determined by the mafic and felsic metavolcanic rocks.

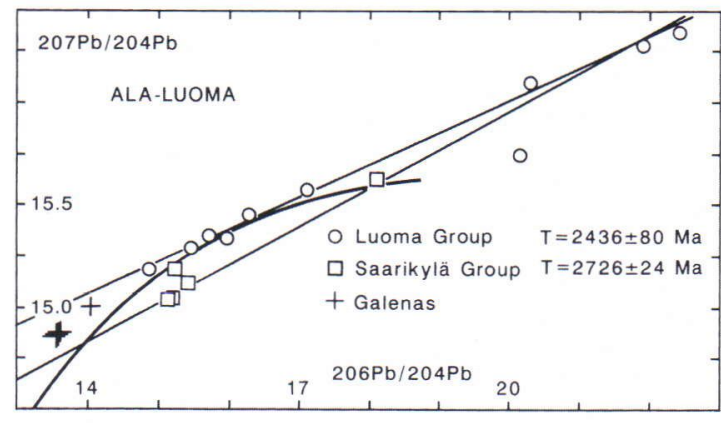

Fig. 7. Results of common lead analyses from the AlaLuoma area. Note the differences in the lead isotopic data between the Luoma Group (open circles) and the Saarikylä Group (open squares) and that the galena leads (crosses) plot off both linear trends. Sample A1192 plots outside the diagram, but lies on the Saarikylä trend.

$\mathrm{Pb}$ deposit (A1174, Fig. 8) yield an age of $2791 \pm 8$ Ma. The error limit is probably somewhat too high, as the slight discrepancy between fractions $B$ and D causes an increase in the MSWD. In view of the high degree of concordancy of the abraded fractions $\mathrm{A}$ and $\mathrm{C}$, a more probable age estimate is $2791 \pm 3 \mathrm{Ma}$. In any case, the result is consistent with the common lead age estimate for the unaltered large whole rock samples from the area $(2744 \pm 70 \mathrm{Ma})$, and thus may be regarded as the true age of the volcanic activity. As the extension of the whole rock isochron passes through the galena lead isotopic composition point of the ore, it 
Table 6. U-Pb mineral data from Taivaljärvi, Ala-Luoma and Saarikylä.

\begin{tabular}{|c|c|c|c|c|c|c|c|c|c|c|}
\hline \multirow[t]{2}{*}{ Sample } & \multirow[t]{2}{*}{ Fraction } & \multirow{2}{*}{$\begin{array}{l}\text { Uconc } \\
\text { ppm }\end{array}$} & \multirow{2}{*}{$\begin{array}{c}\text { Pbconc } \\
\text { ppm }\end{array}$} & \multirow{2}{*}{$\begin{array}{c}206 / 204 \\
\text { meas. }\end{array}$} & \multirow{2}{*}{$\begin{array}{r}206 / 238 \\
\text { Corr }\end{array}$} & \multirow{2}{*}{$207 / 235$} & \multirow{2}{*}{$\begin{array}{l}207 / 206 \\
\text { lank }\end{array}$} & \multicolumn{3}{|c|}{ Apparent age in $\mathrm{Ma}$} \\
\hline & & & & & & & & $6 / 8$ & $7 / 5$ & $7 / 6$ \\
\hline \multicolumn{11}{|c|}{ A1174-Taivaljärvi } \\
\hline A $1174 \mathrm{~A}$ & $+4.5 / \mathrm{abr} 3 \mathrm{~h}$ & 128.0 & 79.90 & 6984 & .5363 & 14.44 & .1953 & 2767 & 2779 & 2787 \\
\hline B & $4.3-4.5$ & 284.7 & 171.10 & 3691 & .5125 & 13.62 & .1928 & 2667 & 2723 & 2766 \\
\hline C & $+4.5 / \mathrm{abr}$ & 134.2 & 85.53 & 2236 & .5384 & 14.49 & .1952 & 2776 & 2782 & 2786 \\
\hline $\mathrm{D}$ & $4.3-4.5$ & 2996.1 & 1816.82 & 3214 & .5151 & 13.66 & .1923 & 2678 & 2726 & 2762 \\
\hline \multicolumn{11}{|c|}{ A1191-Ala-Luoma } \\
\hline A1191A & $+4.2 / \mathrm{abr}$ & 296.2 & 230.40 & 951 & .5545 & 16.42 & .2148 & 2844 & 2901 & 2942 \\
\hline B & $4.0-4.2 / \mathrm{abr}$ & 533.8 & 420.36 & 603 & .5320 & 15.60 & .2127 & 2749 & 2852 & 2926 \\
\hline $\mathrm{C}$ & $3.6-4.0 / \mathrm{abr}$ & 778.6 & 598.86 & 404 & .4929 & 14.09 & .2073 & 2583 & 2755 & 2884 \\
\hline D & $4.0-4.2$ & 531.6 & 364.14 & 821 & .5070 & 14.67 & .2099 & 2643 & 2794 & 2904 \\
\hline \multicolumn{11}{|c|}{ A1192-Saarikylä } \\
\hline A1192A & $4.0-4.2$ & 708.9 & 188.08 & 242 & .1787 & 4.83 & .1960 & 1059 & 1789 & 2793 \\
\hline B & $4.0-4.2$ & 756.1 & 163.96 & 425 & .1583 & 4.39 & .2006 & 947 & 1709 & 2833 \\
\hline C & $3.6-4.0$ & 993.8 & 206.17 & 331 & .1461 & 4.05 & .2010 & 879 & 1644 & 2834 \\
\hline
\end{tabular}

Atomic ratios corrected for common lead.

6/4: 13.40; 7/4: 14.65; 8/4: 33.14 (A1174); 6/4: 13.60; 7/4: 14.86; 8/4: 33.46 (A1191 \& A1192)

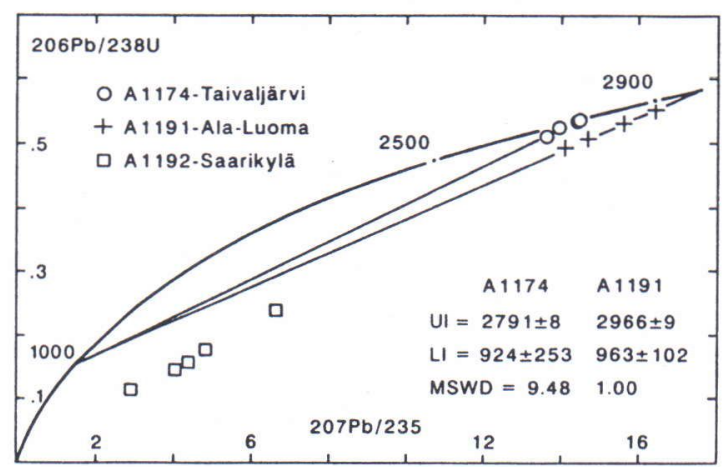

Fig. 8. $\mathrm{U}-\mathrm{Pb}$ results for zircons from the Taivaljärvi, Ala-Luoma and Saarikylä felsic-intermediate metavolcanic rocks.

is highly probable that the volcanism and ore formation were genetically related, and thus the zircon age of the host rocks probably reflects the age of the ore formation as well.

Perhaps the most surprising result is obtained from sample A1191 representing the Luoma metavolcanics. Four slightly discordant zircons give an age of $2966 \pm 9$ Ma (Fig. 8), which is considerably older than data from most other greenstone belt samples indicate. This result supports our previous conclusion that the age of the metavolcanic rocks of the Luoma Group differs considerably from the ages of the rocks elsewhere in the greenstone belt.

The data from sample A1192 representing the Saarikylä Group are very discordant (Fig. 8) and permit only the statement that the rock is of Archaean age. The upper interception age estimate $2918(+141,-121) \mathrm{Ma}$ improves to $2804 \pm 42 \mathrm{Ma}$ when the regression is forced through the origin of the concordia plot, a procedure implying massive recent lead loss from the zircon lattices. When this result is considered together with the whole rock common lead data, it is feasible to suggest that the age of the Saarikylä Group may be about $2790 \mathrm{Ma}$.

\section{DISCUSSION}

The results of this study demonstrate that there is a considerable age difference between the Luoma Group and the other rocks forming the KuhmoSuomussalmi greenstone belt. Whereas the majority of the belt was formed ca. $2790 \mathrm{Ma}$ ago, the Luoma Group predates this event by more than 150 Ma. Moreover, whole rock Rb-Sr (Martin \& 
Quérré 1984) and $\mathrm{Pb}-\mathrm{Pb}$ data demonstrate that the Luoma Group was subjected to an intense reworking about $2500 \pm 100 \mathrm{Ma}$ ago, a feature not detected in the other rocks of the Kuhmo-Suomussalmi greenstone belt. Thus the angular unconformity found in the Ala-Luoma area appears to be a significant block boundary hitherto unrecognized in the Finnish Archaean. Whether such block boundaries are more frequent than previously recognized, and what are their implications for plate tectonic models to be applied to Archaean times, remains an open question.

A fact that emerges from this study is the complexity of Archaean terrains. Thus in the Puukari map sheet area, on the basis of interpretation of field observations, sample A1085-Halmejärvi was regarded older than sample A1086-Haasiavaara. The age data showed, however, that the relationship was opposite. Although no major discordance has been discovered within the Puukari map sheet area, this result, as well as the evidence from sample A1136, suggests that a block boundary similar to the one encountered in the Ala-Luoma area may exist within the Puukari map sheet as well. Another remarkable feature is that ca. $2.7 \mathrm{Ga}$ old granitoids, abundantly occurring only some 20$230 \mathrm{~km}$ northwards (Hyppönen 1983), have not been detected in the Puukari map sheet area. From a practical point of view this means that ancient block boundaries may be only recognizable in Archaean terrains if detailed field work is supported by comprehensive age dating and other isotopic studies.

The present results also have a bearing on the discussion concerning crustal growth rates in late Archaean and early Proterozoic times. The data from Finland suggest that, although 3.1 Ga old tonalites have been encountered at two localities (Kröner et al. 1981, Paavola 1986) and although the Luoma Group is at least $2.97 \mathrm{Ga}$ in age, major intrusive granitoid activity and migmatization commenced as late as $2.83 \pm .02 \mathrm{Ga}$ ago. These rocks preceded the 2.79-2.75 Ga old (Hyppönen 1983, Luukkonen 1988, Vaasjoki et al. 1993) greenstone belts, which in turn were deformed by the intrusion of the $2.75-2.73 \mathrm{Ga}$ granitoids. This event, as is shown by the data from A1088, also involved reworking of pre-existing crustal material.

As the greenstone belts were emplaced between the 2.83 and $2.75 \mathrm{Ga}$ pulses of crustal accretion, the two granitoid events should be considered as representing separate orogenies. On the Puukari map sheet, the next phase of granitoid activity and regional thermal metamorphism occurred at about $2.66 \mathrm{Ga}$. However, consideration of all granitoid age determinations from Finland (Huhma \& Vaasjoki 1989) suggests that crustal formation occurred throughout the $2.75-2.66 \mathrm{Ga}$ time span. The evidence does not allow us to decide whether these events were separate or constituted a continuous regional process and thus the nature of granitoid formation between 2.75 and $2.66 \mathrm{Ga}$ remains obscure. The titanite data show, however, that no regional thermal event exceeding $500^{\circ} \mathrm{C}$ affected the Archaean of the Fennoscandian Shield after $2.65 \mathrm{Ga}$.

The whole rock lead analysis from the youngest granitoid in the area, A1128-Rasimäki, sheds some light on crustal evolution during early Proterozoic times. The lead in this rock has evolved in a low $\mathrm{U} / \mathrm{Pb}$ and high $\mathrm{Th} / \mathrm{U}$ environment, thought to be characteristic of lower continental crust (Doe \& Zartman 1979, Zartman \& Haines 1988). Thus it does not represent generation of new crust, but is rather the result of remobilization of previously formed Archaean lower continental crust. Considering the scarcity of $2.3-2.45$ Ga old granitoids in Finland and the data from this particular sample, it must be concluded that, within the Fennoscandian Shield, there is no evidence for continental crust formed during very early Proterozoic times. Together with data from detrital zircons in the Svecofennian metaturbidites (Huhma et al. 1991), this finding suggests that many of the 2.3$2.4 \mathrm{Ga} \mathrm{Sm}-\mathrm{Nd}$ model ages obtained for early Proterozoic metasedimentary rocks must reflect mixing of materials from various sources rather than a hitherto unrecognized formation of continental crust (c.f. McCulloch 1987, Bowring \& Podosek 1989, Valbracht 1991).

The data on the two ore prospects studied suggest that, whereas the Taivaljärvi Ag- $\mathrm{Zn}-\mathrm{Pb}$ deposit is syngenetic, the Ala-Luoma prospect has 
no common denominator with its host rocks and consequently may be regarded as epigenetic. Moreover, whole rock data on the Luoma Group in particular indicates that these rocks have been subjected to an intense hydrothermal event at about $2500 \pm 100 \mathrm{Ma}$ although the zircon evidence suggests an emplacement age of $2966 \pm 9$ Ma. A fact worthy of speculation is that the hydrothermal activity is, within its limit of error, coeval with the intrusion of layered gabbros (Alapieti 1982) and the emplacement of some quartz porphyries (Luukkonen 1988), both of which occurred at about $2440 \mathrm{Ma}$.

An interesting feature of the lead data is that apart from the analyses from the Luoma Group most whole rock samples from the KuhmoSuomussalmi greenstone belt plot on a linear trend closely resembling the "Finlandia-trend" of Tilton (1983). As the Taivaljärvi galenas form the least radiogenic data point within this group of samples, it may be argued that this actually represents the initial lead of the Kuhmo-Suomussalmi greenstone belt. It should be noted that both mafic and felsic metavolcanic rocks have contained the same initial lead which is significantly higher in ${ }^{207} \mathrm{~Pb}$ than e.g. the Abitibi leads in Canada (op. cit.). If the previously expressed thesis that crustal accretion in the Finnish Archaean mainly occurred between 2.85 and $2.66 \mathrm{Ga}$ is true, this difference in Archaean lead isotopic compositions is suggestive of Archaean mantle heterogeneity. However, as the evidence from the Luoma Group shows, both common lead and $\mathrm{Rb}-\mathrm{Sr}$ systems of ancient rocks may have been altered by subsequent hydrothermal activity.

\section{CONCLUSIONS}

The results presented in this paper, together with previously published data, warrant the following conclusions:

1) Although some dates in excess of $3 \mathrm{Ga}$ have been determined from the Finnish Archaean, most of the granite gneiss terrain was formed between 2.85 and $2.65 \mathrm{Ga}$ with a major period of rock formation at about 2.75 to $2.69 \mathrm{Ga}$.
2) The majority of the metavolcanic rocks within the Kuhmo-Suomussalmi greenstone belt are $2.79 \mathrm{Ga}$ old, but the meta-andesites of the Luoma Group are distinctly older at $2.97 \mathrm{Ga}$.

3) The Taivaljärvi Ag- $\mathrm{Zn}-\mathrm{Pb}$ deposit appears to be syngenetic with the local metavolcanic rocks and is thus $2.79 \mathrm{Ga}$ old. Its lead probably represents the initial lead of both mafic and felsic metavolcanic rocks.

4) When compared to the Abitibi region in Canada, the present data are suggestive of a heterogeneous Archaean mantle. However, it must be noted that such differences, based in this case largely on deviating common lead data, may also arise from later hydrothermal processes.

ACKNOWLEDGMENTS. The authors are indebted to Drs. Erkki Luukkonen and Hannu Huhma of the Geological Survey of Finland and Dr. Torbjörn Skiöld of the Naturhistoriska Riksmuseet, Stockholm, for constructive criticism of the manuscript. The linguistic correction of the English manuscript was done by Mr. Peter Glithero, M.A. Technical assistance by the staff of the Geological Survey of Finland is greatly appreciated.

\section{REFERENCES}

Alapieti, T. 1982. The Koillismaa layered igneous complex, Finland - its structure, mineralogy and geochemistry, with emphasis on the distribution of chromium. Geological Survey of Finland, Bulletin 319. 116 p.

Anhaeusser, C.R. 1971. Cyclic volcanicity and sedimentation in the evolutionary development of Archean greenstone belts of shield areas. Geological Society of Australia, Special Publication 3, 57-70.

Barbey, P. \& Martin, H. 1987. The role of komatiites in plate tectonics. Evidence from the Archean and early Proterozoic crust in the eastern Baltic Shield. Precambrian Research 35, 1-14.

Bowring, S.A. \& Podosek, F.A. 1989. Nd isotopic evidence from Wopmay Orogen for 2.0-2.4 Ga crust in western North America. Earth and Planetary Science Letters 94, 217-230.

Doe, B.R. \& Zartman, R.E. 1979. Plumbotectonics I. The Phanerozoic. In: Barnes, H.L. (ed.) Geochemistry of Hydrothermal Ore Deposits. New York: John Wiley \& Sons, 22-70

Engel, W.W. \& Dietz, G.-J. 1989. A modified stratigra- 
phy and tectonomagmatic model for the Suomussalmi greenstone belt, eastern Finland, based on the remapping of the Ala-Luoma area. Bulletin of the Geological Society of Finland 61, 143-160.

Gaál, G., Mikkola, A. \& Söderholm, B. 1978. Evolution of the Archean crust in Finland. Precambrian Research 6, 199-215.

Gruau, G., Tourpin, S., Fourcade, S. \& Blais, S. 1992. Loss of isotopic (Nd, O) and chemical (REE) memory during metamorphism of komatiites: new evidence from eastern Finland. Contributions to Mineralogy and Petrology $112,66-82$.

Gulson, B.L. \& Mizon, K.J. 1979. Lead isotopes as a tool for gossan assessment in base metal exploration. Journal of Geochemical Exploration 11, 299-320.

Halliday, A.N., Luukkonen, E.J. \& Bowes, D.R. 1988. RbSr whole rock isotopic study of late Archean and early Proterozoic granitoid intrusions, Kainuu, eastern Finland. Bulletin of the Geological Society of Finland 60, $107-113$.

Horneman, R., Hyvärinen, T. \& Niskanen, P. 1988. The granitoids surrounding and intruding the Kuhmo greenstone belt, eastern Finland. Geological Survey of Finland, Special Paper 4, 97-121.

Huhma, H. \& Vaasjoki, M. 1989. Isotopes from granitoids in Finland: a review. Geological Survey of Finland, Special Paper 8, 70 .

Huhma, H., Claesson, S., Kinny, P.D. \& Williams, I.S. 1991. The growth of Early Proterozoic crust: new evidence from Svecofennian detrital zircons. Terra Nova 3, 175-179.

Hyppönen, V. 1983. Ontojoen, Hiisijärven ja Kuhmon kartta-alueiden kallioperä. Summary: Pre-Quaternary rocks of the Ontojoki, Hiisijärvi and Kuhmo map-sheet areas. Geological map of Finland $1: 100$ 000, Explanation to the maps of pre-Quaternary rocks, Sheets 4411, 4412 and 4413. Geological Survey of Finland. 60 p.

Jahn, B.-M., Vidal, P. \& Kröner, A. 1984. Multi-chronometric ages and origin of Archean tonalitic gneisses in Finnish Lapland: a case for long crustal residence time. Contributions to Mineralogy and Petrology 86, 398-408.

Kopperoinen, T. \& Tuokko, I. 1988. The Ala-Luoma and Taivaljärvi $\mathrm{Zn}-\mathrm{Pb}-\mathrm{Ag}-\mathrm{Au}$ deposits, eastern Finland. Geological Survey of Finland, Special Paper 4, 13-144.

Kouvo, O. \& Tilton, G. 1966. Mineral ages from the Finnish Precambrian. Journal of Geology 74, 421-442.

Krogh, T.E. 1973. A low-contamination method for hydrothermal decomposition of zircon and extraction of $U$ and $\mathrm{Pb}$ for isotopic age determinations. Geochimica et Cosmochimica Acta 37, 485-494.

Krogh, T.E. 1982. Improved accuracy of U-Pb zircon ages by the creation of more concordant systems using air abrasion technique. Geochimica et Cosmochimica Acta 46, 637-649.

Kröner, A., Puustinen, K. \& Hickman, M. 1981. Geochronology of an Archean tonalitic gneiss dome in northern Finland and its relation with an unusual overlying conglomerate and komatiitic greenstone. Contributions to Mineralogy and Petrology 76, 33-41.
Luukkonen, E.J. 1985. Structural and U-Pb isotopic study of late Archaean migmatitic gneisses of the Presvecokarelides, Lylyvaara, eastern Finland. Transactions of the Royal Society, Edinburgh: Earth Sciences 76, 401410.

Luukkonen, E.J. 1988. The structure and stratigraphy of the northern part of the late Archaean Kuhmo greenstone belt, eastern Finland. Geological Survey of Finland, Special Paper 4, 71-96.

Luukkonen, E.J. 1992. Late Archaean and early Proterozoic structural evolution in the Kuhmo-Suomussalmi terrain, eastern Finland. Annales Universitatis Turkuensis, Series A 78.37 p.

Luukkonen, E. \& Lukkarinen, H. 1986. Explanation to the stratigraphic map of Middle Finland. Geological Survey of Finland, Report of Investigations 74. 47 p.

Martin, H. 1987. Evolution of granitic rocks controlled by time-dependent changes in petrogenetic processes: examples from the Archean of eastern Finland. Precambrian Research 35, 257-276.

Martin, H. \& Quérré, G. 1984. A 2.5 Ga reworked sialic crust: $\mathrm{Rb}-\mathrm{Sr}$ ages and isotopic geochemistry of late Archean volcanic and plutonic rocks from E. Finland. Contributions to Mineralogy and Petrology 85, 292-299.

Martin, H. \& Barbey, P. 1988. Zircon U-Pb versus Rb-Sr whole rock age data from eastern Finland. Precambrian Research 39, 221-226.

Martin, H., Chauvel, C., Jahn, B.-M. \& Vidal, P. 1983. Rb$\mathrm{Sr}$ and $\mathrm{Sm}-\mathrm{Nd}$ ages and isotopic geochemistry of Archean granodioritic gneisses from eastern Finland. Precambrian Research 20, 79-91.

McCulloch, M.T. 1987. Sm-Nd isotopic constraints in the evolution of Precambrian crust in the Australian continent. In: Kröner, A. (ed.) Proterozoic Lithospheric Evolution. American Geophysical Union, Geodynamics Series 17, 115-130.

Paavola, J. 1986. A communication on the U-Pb and KAr age relations of the Archean basement in the Lapinlahti-Varpaisjärvi area, central Finland. Geological Survey of Finland, Bulletin 339, 7-15.

Papunen, H., Kopperoinen, T. \& Tuokko, I. 1990. The Taivaljärvi $\mathrm{Ag}-\mathrm{Zn}$ deposit in the Archean greenstone belt, eastern Finland. Economic Geology 84, 1262-1276.

Patchett, P.J., Kouvo, O., Hedge, C.E. \& Tatsumoto, M. 1981. Evolution of continental crust and mantle heterogeneity; evidence from Hf isotopes. Contributions to Mineralogy and Petrology 78, 279-297.

Pekkarinen, L.J. 1979. The Karelian formations and their depositional basement in the Kiihtelysvaara-Värtsilä area, east Finland. Geological Survey of Finland, Bulletin $301.141 \mathrm{p}$.

Stacey, J. \& Kramers, J. 1975. Approximation of terrestrial lead isotope evolution by a two-stage model. Earth and Planetary Science Letters 26, 297-221.

Steiger, R.H. \& Jäger, E. 1977. Subcommission on geochronology: convention on the use of decay constants in geo- and cosmochronology. Earth and Planetary Science Letters 36, 359-362.

Taipale, K. 1983. The geology and geochemistry of the 
Archaean Kuhmo greenstone-granite terrain in the Tipasjärvi area, eastern Finland. Acta Universitatis Ouluensis. Series A, Scientiae Rerum Naturalium 151. Geologica 5.96 p.

Taipale, K. 1988. Volcanism in the Archean Kuhmo greenstone belt, eastern Finland. Geological Survey of Finland, Special Paper 4, 151-160.

Taipale, K., Horneman, R. \& Hyvärinen, T. 1993. Puukari. Geological Map of Finland 1:100 000. Pre-Quaternary rocks. Sheet 4322. Geological Survey of Finland.

Tilton, G. 1983. Evolution of the depleted mantle: the lead perspective. Geochimica et Cosmochimica Acta 47, 1191-1197.

Vaasjoki, M. 1988. Zircon U-Pb versus Rb-Sr whole-rock age data from eastern Finland: A critical comment on the papers of Barbey \& Martin and Martin, Precambrian Research, Vol. 35, 1987. Precambrian Research 39, 217-219.

Vaasjoki, M. 1989. Leads from late Archean and early Proterozoic mineralization in the Fennoscandian Shield: constraints on early crust-forming processes. Geological Survey of Finland, Special Paper 10, 31-32.

Vaasjoki, M. \& Sakko, M. 1988. The evolution of the Raahe-Ladoga zone in Finland: isotopic constraints. Geological Survey of Finland, Bulletin 343, 7-32.

Vaasjoki, M., Ward, P. \& Lavikainen, S. 1993. U-Pb zircon ages and sulfide $\mathrm{Pb}-\mathrm{Pb}$ characteristics from the late Archean Hattu schist belt, Ilomantsi, eastern Finland. Geological Survey of Finland, Special Paper 17, 103131.

Valbracht, P.J. 1991. Early Proterozoic continental tholeiites from western Bergslagen, Central Sweden, II. Nd and $\mathrm{Sr}$ isotopic variations and implications from $\mathrm{Sm}-\mathrm{Nd}$ systematics for the Svecofennian sub-continental mantle. Precambrian Research 52, 215-230.

Vidal, P., Blais, S., Jahn, B.-M., Capdevila, R. \& Tilton, G. 1980 . U-Pb and Rb-Sr systematics of the Suomussalmi Archean greenstone belt (Eastern Finland). Geochimica et Cosmochimica Acta 44, 2033-2044.

Wetherill, G., Kouvo, O., Tilton, G. \& Gast, P. 1962. Age measurements of rocks from the Finnish Precambrian. Journal of Geology 70, 74-88.

York, D. 1969. Least squares fitting of a straight line with correlated errors. Earth and Planetary Science Letters 5, 320-324.

Zartman, R.E. \& Haines, S.M. 1988. The plumbotectonic model for $\mathrm{Pb}$ isotopic systematics among major terrestrial reservoirs - A case for bi-directional transport. Geochimica et Cosmochimica Acta 52, 1327-1339.

\section{APPENDIX: ANALYTICAL TECHNIQUES}

Minerals were separated by gravimetric and magnetic means, sieving and hand-picking. Some fractions were air abraded (Krogh 1982). The sample size was $1-10 \mathrm{mg}$ for zircons and about $30 \mathrm{mg}$ for titanites. Zircons were combusted using the method of Krogh (1973) and titanites and whole rock powders $(200 \mathrm{mg})$ were dissolved in Savillex vials in a 1:1 mixture of $\mathrm{H}_{2} \mathrm{~F}_{2}$ and $\mathrm{HNO}_{3}$.

The isotopic composition of $\mathrm{Pb}$ and the $\mathrm{U}$ and $\mathrm{Pb}$ concentrations were determined by mass-spectrometry and isotope dilution. The Pb blank remained under $500 \mathrm{pg}$ for the zircons and under 1 ng for titanites and whole rocks. The common $\mathrm{Pb}$ correction was based on the galenas from the Taivaljärvi deposit. The reported $\mathrm{Pb} / \mathrm{U}$ ratios are accurate within $\pm 0.8 \%$.

The linear regressions were calculated assuming a 95\% error correlation (York 1969). The age calculation is based on accepted decay constants (Steiger \& Jäger 1977). All error estimates are quoted on $2 \sigma$-level.

Some representative zircons were analysed for their $\mathrm{ZrO}_{2}, \mathrm{HfO}_{2}, \mathrm{Ce}_{2} \mathrm{O}_{3}, \mathrm{Y}_{2} \mathrm{O}_{3}$ and $\mathrm{SiO}_{2}$ contents on an electron microprobe. Some analyses were done in the line-scan mode, i.e. several points from the core to the rim of crystals were measured. Also, back-scatter electron images of representative crystals were recorded.

$\mathrm{U}$ and $\mathrm{Pb}$ from the zircons were extracted using the anion exchange method of Krogh (1973), while the rock and sulphide samples were treated by the combined anion exchange and anodic electrodeposition procedure described by Gulson and Mizon (1979).

At the $2 \sigma$-level, the accuracy of the reported results are: $\pm 0.8 \%$ for the $\mathrm{U} / \mathrm{Pb}$ ratios on zircons and $\pm 0.12 \%$ for the ${ }^{204} \mathrm{~Pb}$-related ratios of the common lead analyses. The common lead results were normalized to the accepted values of the SRM981 and CIT standards. 